\title{
Effects of Densification on Urban Microclimate-A Case Study for the City of Vienna
}

\author{
Wolfgang Loibl ${ }^{1, *(\mathbb{D}}$, Milena Vuckovic ${ }^{2} \mathbb{D}$, Ghazal Etminan ${ }^{1}$, Matthias Ratheiser ${ }^{3}$, Simon Tschannett $^{3}$ \\ and Doris Österreicher ${ }^{4}$ (D)
}

check for

updates

Citation: Loibl, W.; Vuckovic, M.;

Etminan, G.; Ratheiser, M.;

Tschannett, S.; Österreicher, D. Effects

of Densification on Urban

Microclimate-A Case Study for the City of Vienna. Atmosphere 2021, 12,

511. https://doi.org/10.3390/

atmos12040511

Academic Editors:

Hideki Takebayashi and Jihui Yuan

Received: 28 March 2021

Accepted: 13 April 2021

Published: 17 April 2021

Publisher's Note: MDPI stays neutral with regard to jurisdictional claims in published maps and institutional affiliations.

Copyright: (c) 2021 by the authors. Licensee MDPI, Basel, Switzerland. This article is an open access article distributed under the terms and conditions of the Creative Commons Attribution (CC BY) license (https:/ / creativecommons.org/licenses/by/ $4.0 /)$.
1 AIT Austrian Institute of Technology, Giefinggasse 6, 1210 Vienna, Austria; ghazal.etminan@ait.ac.at

2 VRVis Zentrum für Virtual Reality und Visualisierung Forschungs-GmbH, Donau-City-Straße 11, 1220 Vienna, Austria; vuckovic@vrvis.at

3 Weatherpark GmbH, Gardegasse 3, 1070 Vienna, Austria; matthias.ratheiser@weatherpark.com (M.R.); simon.tschannett@weatherpark.com (S.T.)

4 Department of Landscape, Spatial and Infrastructure Sciences, Institute of Spatial Planning, Environmental Planning and Land Rearrangement, University of Natural Resources and Life Sciences, 1190 Vienna, Austria; doris.oesterreicher@boku.ac.at

* Correspondence: wolfgang.loibl@ait.ac.at; Tel.: +43-505509-4587

\begin{abstract}
Climate adaptation, mitigation, and protecting strategies are becoming even more important as climate change is intensifying. The impacts of climate change are especially tangible in dense urban areas due to the inherent characteristics of urban structure and materiality. To assess impacts of densification on urban climate and potential adaptation strategies a densely populated Viennese district was modeled as a typical sample area for the city of Vienna. The case study analyzed the large-scale densification potential and its potential effects on microclimate, air flow, comfort, and energy demand by developing 3D models of the area showing the base case and densification scenarios. Three methods were deployed to assess the impact of urban densification: Micro-climate analysis (1) explored urban heat island phenomena, wind pattern analysis (2) investigated ventilation and wind comfort at street level, and energy and indoor climate comfort analysis (3) compared construction types and greening scenarios and analyzed their impact on the energy demand and indoor temperatures. Densification has negative impacts on urban microclimates because of reducing wind speeds and thus weakening ventilation of street canyons, as well as accelerating heat island effects and associated impact on the buildings. However, densification also has daytime cooling effects because of larger shaded areas. On buildings, densification may have negative effects especially in the new upper, sun-exposed floors. Construction material has less impact than glazing area and rooftop greening. Regarding adaptation to climate change, the impacts of street greening, green facades, and green roofs were simulated: The 24-h average mean radiant temperature (MRT) at street level can be reduced by up to $15 \mathrm{~K}$ during daytime. At night there is only a slight reduction by a few tenths of $1 \mathrm{~K}$ MRT. Green facades have a similar effect on MRT reduction, while green roofs show only a slight reduction by a few tenths of $1 \mathrm{~K}$ MRT on street level. The results show that if appropriate measures were applied, negative effects of densification could be reduced, and positive effects could be achieved.
\end{abstract}

Keywords: urban microclimate; urban fabric; urban densification; microclimate simulations; urban heat island effect; climate adaption measures; thermal comfort; building refurbishment; building simulation

\section{Introduction}

Although adaptation to climate change has always been highlighted as important alongside the mitigation of climate change [1], more emphasis has been laid in the past on climate protection. The Paris Agreement in November 2016 [2] has finally stressed protection and adaptation as equally important, strengthening the efforts of many countries 
that have already developed national adaptation strategies and motivating others to follow. Urban climate and climate change are issues of growing importance with respect to urban neighborhoods as well as entire cities.

Urban land cover is estimated to substantially increase by around 1,527,000 $\mathrm{km}^{2}$ until 2030 [3] and the urban population is growing worldwide at a steady rate with a rise from $55 \%$ in 2018 to a projected $68 \%$ of people living in cities across the globe in 2050 [4]. On the other hand, the number of people per household is decreasing, a fact that could be mostly attributed to socio-demographic trends that include aging population, declining fertility rates, single parent households, and single households. At the same time, the floor space of individual homes is increasing, especially in developed countries [5]. Globally, over the last 25 years in over $40 \%$ of urban centers the rate of demographic growth has been greater than the one of spatial expansion [6].

The city of Vienna is amongst those growing cities, with an estimated rise of almost 300,000 inhabitants until 2048 [7]. The administrative boundaries of the city have conversely remained untouched since 1954 and this will change in the future. To accommodate the rising population moving to the city, new residential buildings and associated infrastructure must be provided. Since the city does not want to expand excessively and is planning to keep its green belt (with forest, nature reserve, and agricultural areas) along its borders, the density of the already built-up area needs to be increased. But this shall be carried out by increasing the building height in a moderate way and to a lesser extent through sealing of additional surface area. However, much of the quality of life in the city is due to its large quantity of green spaces, with $31 \%$ of the overall urban area consisting of publicly available green spaces [8].

As the urban population steadily grows, anthropogenic heat flux is similarly increasing and subsequently speeding up the urban heat island effect. Thus, climate dynamics must be considered in combination with urban changes, requiring adaptive activities to better cope with urban dynamics under future climate change. This is of importance as temperatures are increasingly on the rise during the summertime. For Vienna, a moderate increase of up to 25 summer days (days with maximum air temperature exceeding $25^{\circ} \mathrm{C}$ ) is expected for the period 2021-2050 and 20 to 50 days per year for the period until 2100 [9]. While (horizontal) urban growth has been considered with respect to urban microclimate and climate change $[10,11]$, urban densification has been less explored to be an issue affecting urban microclimate, specifically with respect to heat island effects and air flow. Overall densification measures may have a substantial impact on both microclimate and energy demand in cities; thus, energy-sensitive densification strategies must be integrated in long-term urban regeneration policies [12]. At the same time, adaptation and mitigation actions need to be carefully balanced in densely populated areas [13].

In a research project within the funding framework of the Austrian Climate Research Program (ACRP 10th call, grant number KR17AC0K13790), the project "CLUDEX—Climate Change and urban densification impact exploration" has carried out a series of interdisciplinary investigations into the effects of urban densification measures. This paper builds on the results and recommendations of the final activity report [14]. The project investigated dependencies between urban densification and urban climate under current climate and global warming conditions by means of wind, microclimate, and building simulations based on a case study in a densely built-up urban district of the city of Vienna. The study builds on the hypothesis that specific urban and building densification measures can positively or negatively impact the urban microclimate and energy demand, as well as comfort for its citizens. Subsequently, the research questions focused on how densification affects the urban microclimate and which mitigation measures on an urban and building planning level could be most effective. The key findings and conclusions are subsequently summarized in this paper. 


\section{Background}

As climate change is progressively affecting our rural and urban habitats, the need for adaptation and mitigation measures is intensifying. In densely populated and built-up urban areas, the impact of climate change is accelerated as natural surfaces are largely replaced by sealed cover and building sites. This has the destructive effect that less green area is available and that the built infrastructure multiplies the amount of thermal mass and consequently heat storing materials in the third dimension. An increasing population, however, needs additional living space and associated infrastructure; thus, densification shall be conducted without additional land use. It is therefore key to specifically identify climate-sensitive urban systems and provide recommendations for appropriate measures.

Mahtta et al. identified in their analysis on 478 cities across the world with one million or more inhabitants five distinct urban growth and densification typologies: Budding outward, stabilized, outward, upward and outward, and mature upward [15]. Densification measures can also be combined with building refurbishment and can subsequently significantly contribute to an upgrade of certain neighborhoods. Attic extensions, if carried out to high efficiency standards, can increase the building quality and property value, and can improve the living comfort of the inhabitants and reduce the overall energy demand for heating and cooling [16].

When assessing urban growth and densification measures, especially also related to horizontal expansion where additional land might be sealed, the effects of greening should be considered. Blue-green infrastructure, defined as an interconnected network of natural and designed landscape components, is considered an essential element in mitigating the effects of climate change [17] and in particular in reducing the consequences that lead to increased flooding [18]. Green infrastructure can be implemented in a variety of measures. Categorizing them in terms of approach can help to accelerate implementation. Actions can be practical, educational, or participatory, and can be seen as positive in terms of their landscape for the micro-climate, health, and aesthetic value [19]. The urban microclimate can be improved if suitable mitigation measures are considered. Increasing vegetation, de-sealing surfaces and roof greening are cited as suitable actions within the "Urban Heat Island Strategy Plan" of the city of Vienna [20].

The retrofitting of roofs and facades with plants can thus contribute to ease the urban heat island effect [21]. Especially vulnerable communities, with less potential for alternative cooling options, can benefit from green roofs [22]. For facades it is, however, important to note that the plants should not hinder solar access during the winter months. Thus, green facades that lose their foliage in winter are preferable [23]. A study by Chun et al. has also shown that green urban spaces reduce temperatures during the summer and increase them during winter months, thus concluding that seasonal effects must be considered when implementing green infrastructure [24].

However as renewable energy increasingly needs to be incorporated into the building shell if ambitious climate targets are to be met, green roofs are also competing for space with the application of photovoltaic or solar thermal systems. Combining the benefits of green roofs with the generation of renewable energy is thus of utmost importance. Nevertheless, the number of solar green roofs is still low, with only a few applications in 2018 and virtually none a few years before [25]. Novel applications such as the "PV-Rooftop-Garden" provide suitable solutions to combine the positive effects of green roofs and PVs [26].

In buildings, summertime overheating becomes, also in temperate climates, increasingly problematic as consecutive days with high temperatures are on the rise. Several studies have already found that Urban Heat Islands (UHI) influence cooling energy consumption $[27,28]$. By reducing the internal room temperature through extensive roof greening, less energy is also required for active cooling systems [29]. Future energy scenarios show that highly insulated buildings, such as net zero energy dwellings, can have an increasing overheating risk [30]. A similar effect has also been assessed for passive houses [31]. Oikonomou et al. came to the conclusion that the thermal quality of a dwelling can have a greater impact on indoor temperatures than the UHI [32]. The current high 
insulation standards can thus have an adverse effect related to overheating and rapid cooling by lower night temperatures, not being easily achieved [33]. Nevertheless, there are a series of passive architectural measures, such as external solar shading, high thermal mass, and night ventilation that can also be implemented in order to avoid summertime overheating in well-insulated buildings [34]. Specific strategies can mitigate the effects of the high-quality building shell, even in passive houses and super-insulated buildings [35-37]. The type of construction similarly affects the energy demand but also the internal room temperature. A heavy-weight construction shows through the higher inertia a slower thermal response than a light-weight construction [38]. For Vienna, overheating in buildings is regulated within the respective building codes and evidence must be provided that overheating is kept within specific temperature boundaries [39].

The densification of the urban fabric, however, does not only affect the buildings as such but also the overall urban morphology of the city. Changing the height and shape of a larger number of buildings within a district can change the aerodynamic properties of the urban fabric over time. It can also increase or decrease ventilation and accelerate heat trapping in the city. The goal is therefore to improve the urban microclimate and at the same time increase thermal comfort in and around buildings and optimize energy efficiency. Addressing and evaluating the climate impact of the vertical extension of buildings is rather complex, especially if a variety of scenarios based on different policies must be explored.

On a building level, precise information about physical and functional characteristics can be carried out with a variety of simulations tools and organized in a building information model (BIM) [40]. Moving from the single-building dimension up to the urban or at least neighborhood scale requires a somewhat similar but to some extent different approach which is generally defined as city information modeling (CIM) and which is meant to enable street block and finally city-wide detailed knowledge of all relevant objects. To this extent, semantic 3D city models are relatively new, capable of dealing with the third dimension, and are conceived to help in overcoming the intrinsic difficulty of creating, collecting, and homogenizing large amounts of both spatial and non-spatial heterogeneous data [41]. The term semantic 3D city model does not only refer to geometry but also to semantics (e.g., building usage, construction date, and materials) and topology (e.g., adjacency to other buildings, shared walls). In this context CityGML (City Geography Markup Language) is applied - an open XML-based format for the storage and exchange of virtual 3D city models, accepted as international data model standard [42]. The benefits tied to a spatial-semantically coherent urban model [43] are various, as well as the possibilities to exploit such a model for applications ranging from urban planning to augmented reality to utility network management to energy simulation tools. An extensive list of further applications can be found in Biljecki et al. [44].

There is however a clear research gap in bringing the urban level (microclimate, comfort) together with the building level (internal comfort, energy) in relation to vertical densification. This is one of the key aspects this study aims at addressing in order to provide recommendations for future densification strategies in cities.

\section{Methods}

In order to assess impacts of densification on urban climate and potential adaptation strategies a densely populated Viennese district was modeled as a typical sample area for the city of Vienna. The case study focused on Meidling, the 12th district of Vienna, and analyzed the large-scale densification potential and its potential effects on microclimate, air flow, comfort, and energy demand. For the analysis, three methods as outlined below were deployed to assess the impact of urban densification. Micro-climate analysis (1) assessed the effect related to urban heat island phenomena. Wind pattern analysis (2) investigated wind speed and wind comfort at street level. The energy and internal comfort analysis (3) compared different construction types and greening scenarios and analyzed their impact on the energy demand and internal temperatures of buildings. In addition, adaptation alternatives were discussed with public stakeholders, and the results were fed into urban 
planning guidelines. More specifically, stakeholders from local authorities were involved to define adaptation measures to better cope with local heat increase, as well as to the effects of urban densification.

The densification scenarios were conducted for the entire central Meidling as a study area based on the building height zoning maxima as outlined in the current land use and zoning plan and subsequent zoning height regulations for the city of Vienna. Spatially explicit scenarios were carried out through 3D city models, considering building footprints and building height. The initial 3D city model was generated using the built-in generative algorithms within the Rhinoceros 3D plug-in environment Grasshopper [45]. The base date was derived from geodata, provided by the city of Vienna, showing building footprints with building height information, from street level to building eave. Information regarding the maximum allowed building height based on the Vienna zoning plan [45] was integrated into the geodata base through a spatial relation of the height class annotation of the development plan - the height zoning - to the building footprints of the geodata base using ArcGIS software. Once the initial geometric input was prepared, 3D geometry representing both base case and densification scenarios was generated. The process provided the automated upward extrusion of building footprints transferring the buildings' height information into 3D volumes (Figures 1 and 2). The difference between current and possible maximum building heights allowed us to estimate the additional number of possible floors (with and without attic extension) for each building. Based on the building footprint size and the number of additional floors, the additional potential gross floorspace was estimated and summarized for the entire area.

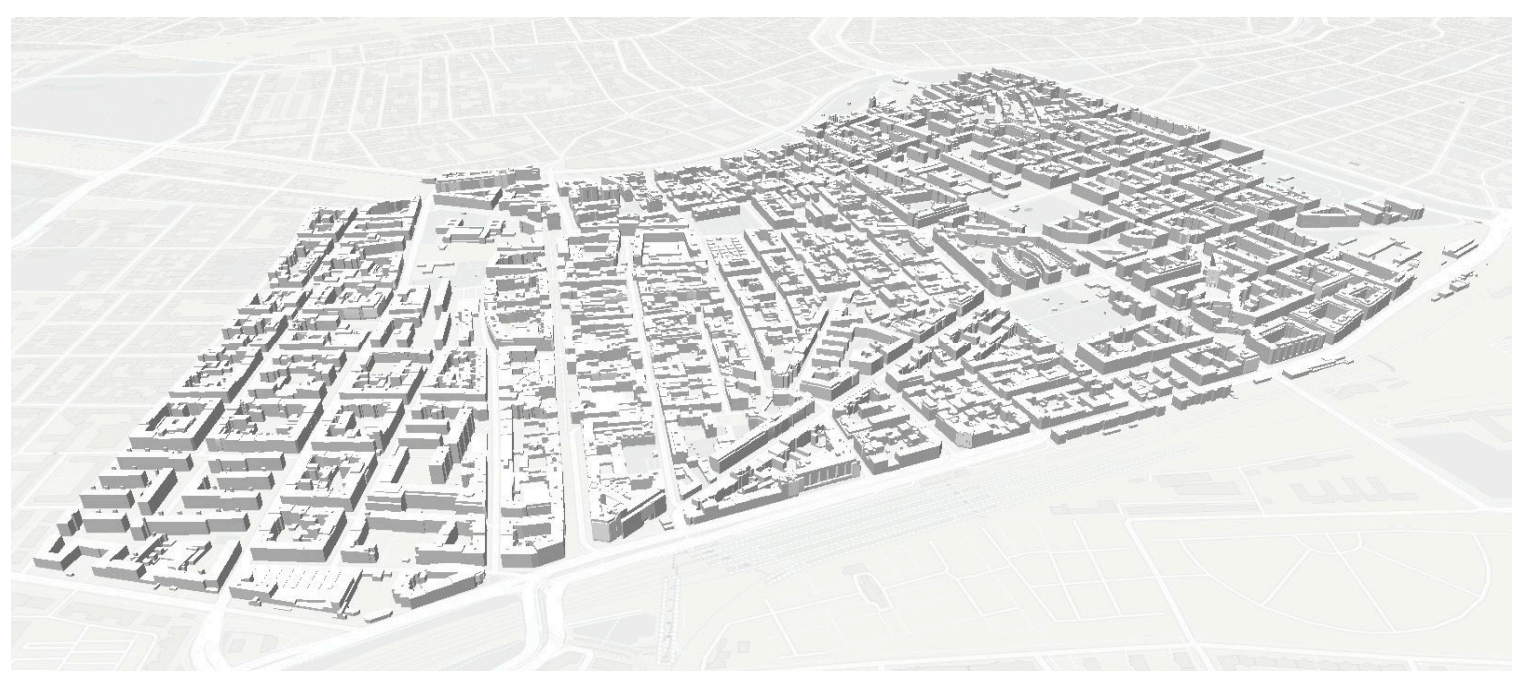

Figure 1. 3D model of the study area: Base case depicting the current volumes developed from the Land Use and Zoning Plan of the City of Vienna [46].

The overall floorspace extension potential was quantified for the residential and mixeduse buildings by taking current building height, maximum building height, and building footprint area from the building footprint geodata base. Hypothetical height extensions were only considered for buildings if the footprint exceeded $100 \mathrm{~m}^{2}$ in order to cater for a realistic size for an additional flat. Differences between the current and the potential maximum elevation were only considered when the height difference was higher than $1.5 \mathrm{~m}$ to serve as additional floor space, at least as attic floor space. Backyard buildings were only included for height extension if their current height was above $4 \mathrm{~m}$, otherwise they were considered as workshop buildings and backyard sheds, not feasible for residential floorspace extension. 


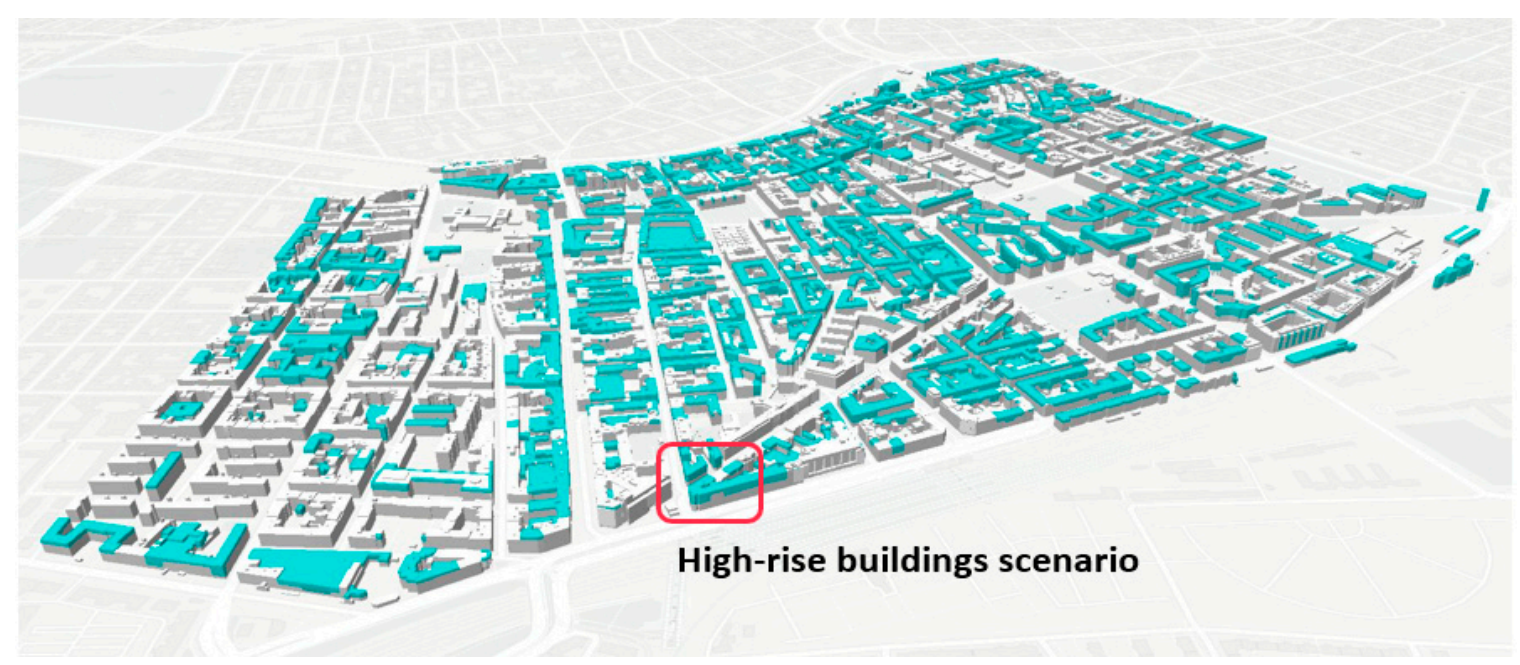

Figure 2. 3D model of the study area: Densification scenario including the volumes for maximum allowable building height (marked in blue) and the location of a hypothetical high-rise buildings cluster.

Compared to the actual building height distribution in Meidling, the height zoning regulation allowed for a substantial extension of many buildings where the height is currently well below the height zoning limits. The current gross floor area (GFS) in the study area was around 2.8 million $\mathrm{m}^{2}$ with the GFS extension potential by means of regular floors amounting to $467.000 \mathrm{~m}^{2}$ and including attic conversions up to $701.000 \mathrm{~m}^{2}$. This resulted in a maximum GFS extension potential of $16 \%$. With the inclusion of attic conversions, the growth potential could add up to $25 \%$ of the GFS. Thus, urban densification in central Meidling would allow for an additional 6.600 to 9.900 flats by considering an average flat size of around $94 \mathrm{~m}^{2}$ GFS [47]. See Figure 2 for the general densification scenario including the maximum allowable building height. In addition, an area for a hypothetical high-rise building cluster with two buildings of 80 and $100 \mathrm{~m}$, respectively, was defined to study the effects of increased heights on the urban microclimate as also indicated in Figure 2.

The base case and densification scenarios provide the basis for the analysis related to microclimate, wind, energy, and indoor climate as outlined below.

\subsection{Microclimate Analysis}

Microclimate simulations were conducted applying a set of plug-ins from the family of Ladybug tools such as the Grasshopper toolset within Rhinoceros 3D [48]. The Ladybug plug-in components inherit the physical principles and functionalities of its underlying simulation engines.

The Ladybug component Honeybee enabled us to simulate microclimatic effects in urban environments under different climate framework conditions to investigate urban heat island phenomena and related adaptation measures, by modeling the small-scale interactions between individual buildings, surfaces, and plants. The Ladybug components allowed the computation of complex interactions of the built environment and local climate by considering a unique position of the study domain and by solving intersections between solar vectors and physical obstructions of the built environment such as buildings or trees [49]. The simulations were conducted in three subsets as shown in Figure 3 to consider both the extent of the study area as well as more detailed simulations. One subset was subsequently carried out for the entire study area along the Meidlinger Hauptstraße (Figure $3 \mathrm{a}, \mathrm{b}$ ), a second one was conducted on a smaller sample area of some building blocks in the center of the Meidlinger Hauptstraße (Figure 3c,d), and a third one for a theoretical high-rise building cluster at the edge of the study area (Figure 3e,f). For a future climate scenario, the input weather file was modified using extreme heat day characteristics from 
Austrian climate simulations, downscaled for Vienna to a $1 \times 1 \mathrm{~km}$ grid for the year 2041, which constitutes the most extreme year until 2050 [50].

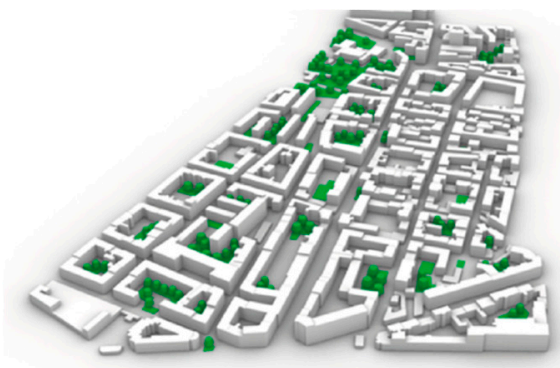

(a)

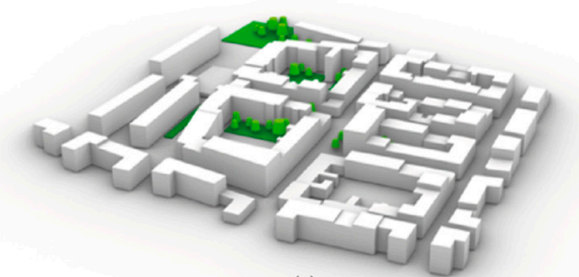

(c)

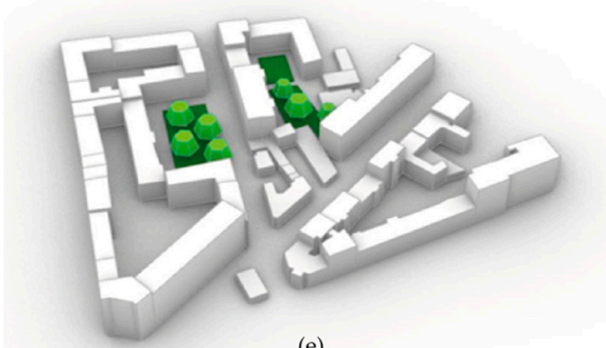

(e)

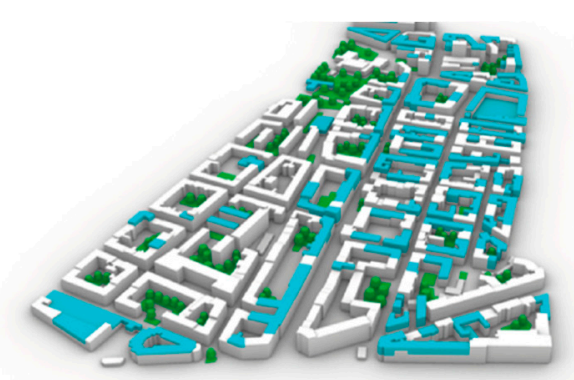

(b)

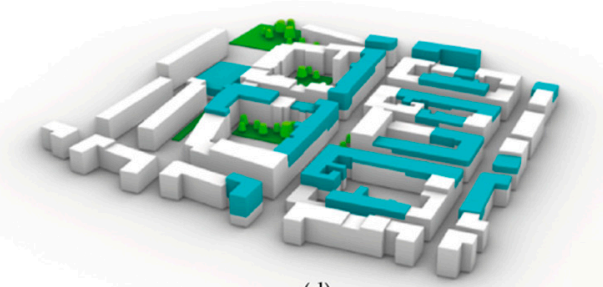

(d)

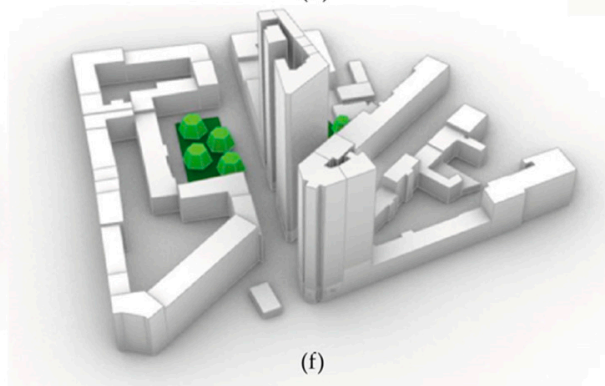

Figure 3. 3D model for the microclimate simulations for three subsets of the study area: Large domain for simulating large-scale general densification impacts for base case (a) and densification scenarios (b); sub-domain for simulating impacts of adaptation measures for base case (c) and densification scenarios (d); location for the simulation of the impact of a high-rise cluster for the base case (e) and densification scenarios (f).

\subsection{Wind Analysis}

To conduct wind field simulations for the main wind directions and speeds, the frequencies of wind directions and windspeed classes were explored based on the monitoring results for a 30-year climate period (1989-2018) and for the subset of heat days $\left(>30^{\circ} \mathrm{C}\right.$ Tmax) during this period. The wind simulations were carried out using a computational fluid dynamics (CFD) model applying the software STAR-CCM+ [51] to calculate full 3D flow fields. Wind fields were modeled for the study area considering the current building height and the densification scenario by applying the main wind directions and wind speeds measured during heat waves. In addition, local wind fields were modeled for the hypothetical high-rise building cluster in the south of the study area. The goal was to combine the advantages of CFD wind simulations with a methodology for providing fresh air supply. While the classic urban ventilation models covering large areas used mostly parameterized land cover categories as surface roughness to represent buildings and terrain (e.g., [52]), with a CFD model, every single building of an urban quarter could be explicitly modeled. This enabled the generation of results that quantified the impact of large building structures or street canyons on the city's ventilation.

For the 30-year wind pattern analysis (1989-2018), data from a close weather station was applied. The analysis showed that the prevailing wind direction during heat days was southeast with rather low to moderate wind speeds, mostly between 3 and $5 \mathrm{~m} / \mathrm{s}$. 
Wind from all other directions during hot days showed wind speeds between 1 and $3 \mathrm{~m} / \mathrm{s}$ (Figure 4).

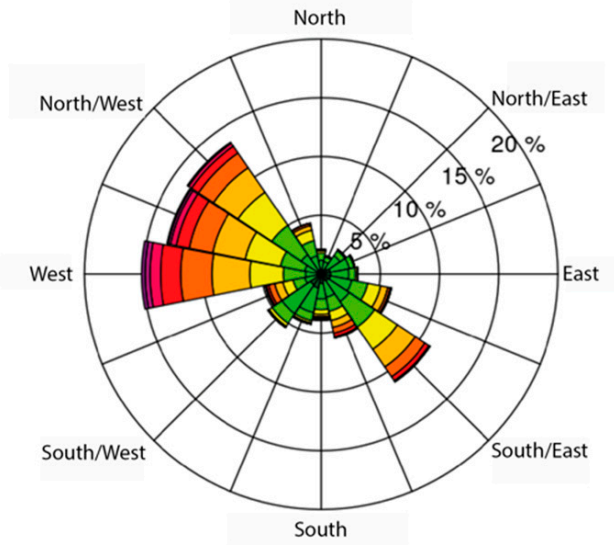

Data Set 1989 - 2018; no wind periods: 0,2\%

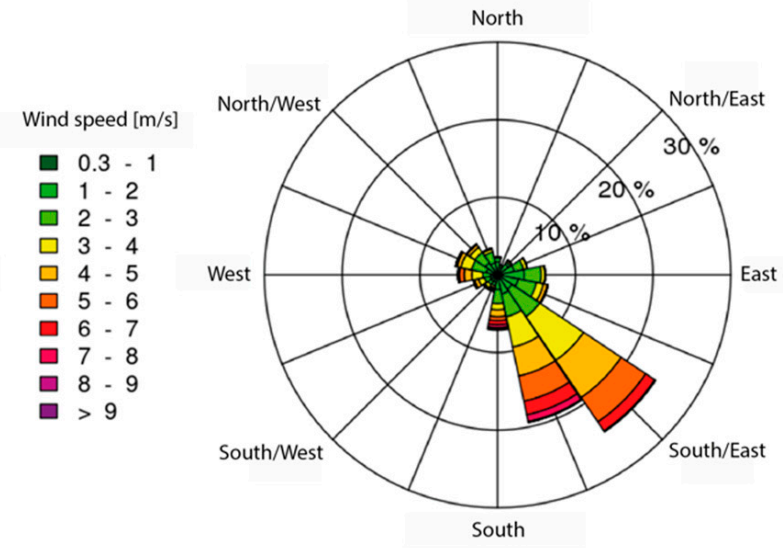

Temperature $>30^{\circ} \mathrm{C}, 1989-2018$

Figure 4. Windrose diagrams: Average wind speeds (color) and directions (bars) observed at the inner city weather station in Vienna for all weather situations (left) and for hours with temperatures $>30^{\circ} \mathrm{C}$ (right).

Based on these datasets, uncomfortable wind speeds (exceeding $12 \mathrm{~km} / \mathrm{h}$ ) were analyzed. The map below displays the wind characteristics in central Meidling, combining all 16 wind directions related to uncomfortable conditions (Figure 5). Street areas where the number of hours per year with uncomfortable conditions exceeded $1.200 \mathrm{~h}$ (yellow, orange, and red) were considered to have a low wind comfort. Streets marked in green indicated high wind comfort. In the study area, most streets showed high wind comfort, with only several crossings and long, straight roads in line with the main wind directions, as well as the areas bordering the railway tracks in the south and the western, more open areas having lower wind comforts.

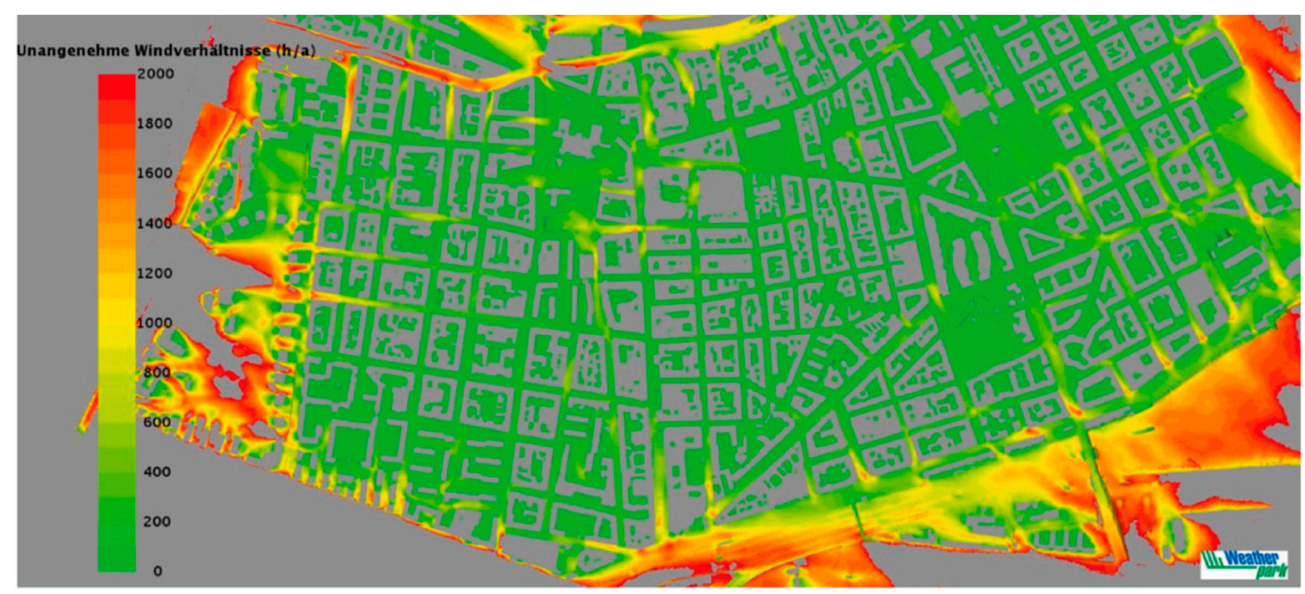

Figure 5. Number of hours per year (in the map's legend abbreviated as "h/a" (hours per annum)) with uncomfortable wind speeds.

\subsection{Indoor Climate Analysis}

Densification measures may also affect indoor climate and thus the overall energy demand of buildings for heating and cooling to provide indoor comfort temperatures. In order to assess effects of building height increase (of existing buildings) two exemplary buildings within the study area which showed a high potential for vertical extension and represent typical building types were selected for a detailed analysis.

The height of two buildings was (theoretically) extended through modeling to the maximum allowable building height based on the height zoning plan. For this theoretical 
extension, constructive aspects (such as potentials of load bearing elements) or building design improvement aspects (like facade structuring or inclusion of balconies) were discounted in this context. The buildings were subsequently simply extended based on the footprint of the underlying, existing buildings. The facade of the additional floors was assumed to match with the existing building (window to wall ratio). Only for the additional glazing case was the window area doubled in the last floor. Subsequently, the building could integrate 3 or 4 additional levels for flat roof extension and 2 or 3 levels and an attic extension for the slanted roof extension. In Figure 6, the additional floors of the extended building parts are shown in green and the attic conversions are shown in red.
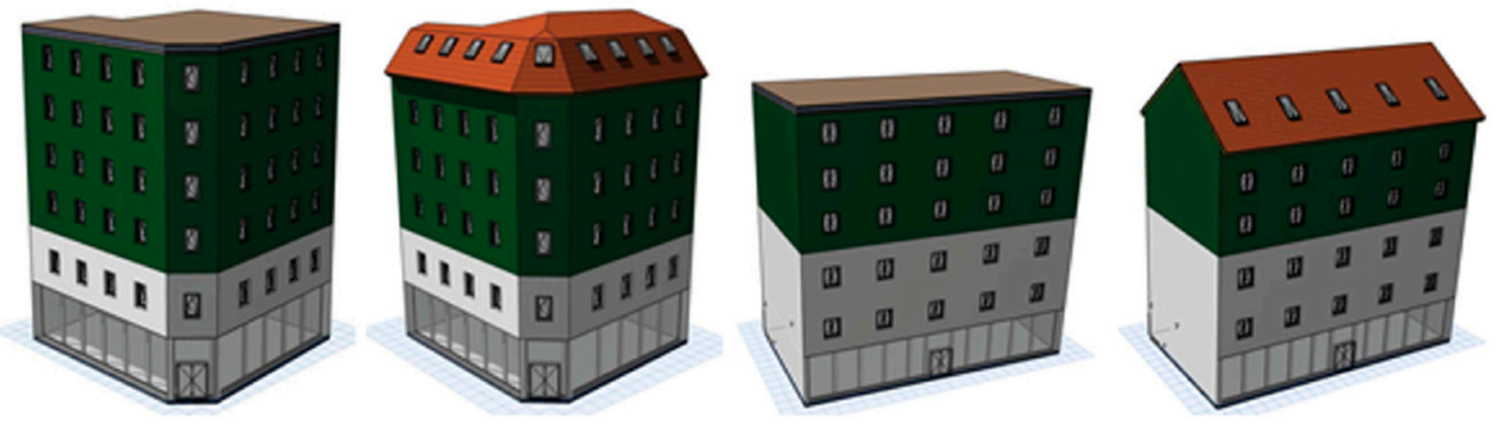

Figure 6. Theoretical vertical extensions of the case study buildings with the floor extensions shown in green with flat and slanted roofs $[53,54]$.

The extensions of both building were modeled and analyzed with different construction types (lightweight and heavy-weight construction) and with greening of the roof and facade. The modeling was conducted in AutoCAD and SketchUp. Energy demand analysis was carried out with ArchiPhysik [55] and indoor climate comfort analysis with Thesim3d [56]. The simulation was compiled within two master thesis works within the framework of the project as documented in $[53,54]$.

To compare the effects of different construction types, various aspects of the building shell and structure were altered as outlined in Table 1.

Table 1. Overview: buildings extensions with different construction types [53].

\begin{tabular}{|c|c|c|c|}
\hline A. Roof Type & B. Glazing & C. Light-Weight Construction & D. Heavy-Weight Construction \\
\hline \multirow{4}{*}{ Flat roof } & \multirow{2}{*}{ Equal to existing building } & $\begin{array}{l}\text { Wall with cellulose insulation and } \\
\text { inverted roof }\end{array}$ & $\begin{array}{l}\text { Solid wood wall with intermediate } \\
\text { insulation and inverted roof }\end{array}$ \\
\hline & & $\begin{array}{l}\text { Ventilated wall with wooden } \\
\text { paneling and inverted roof }\end{array}$ & $\begin{array}{l}\text { Concrete wall with external } \\
\text { insulation and inverted roof }\end{array}$ \\
\hline & \multirow{2}{*}{$\begin{array}{l}\text { Twice that of existing building } \\
\text { in last floor }\end{array}$} & $\begin{array}{l}\text { Wall with cellulose insulation and } \\
\text { inverted roof }\end{array}$ & $\begin{array}{l}\text { Solid wood wall with intermediate } \\
\text { insulation and inverted roof }\end{array}$ \\
\hline & & $\begin{array}{l}\text { Ventilated wall with wooden } \\
\text { paneling and inverted roof }\end{array}$ & $\begin{array}{l}\text { Concrete wall with external } \\
\text { insulation and inverted roof }\end{array}$ \\
\hline \multirow{4}{*}{ Sloping roof } & \multirow{2}{*}{ Equal to existing building } & $\begin{array}{l}\text { Wall with cellulose insulation and } \\
\text { ventilated rafter roof }\end{array}$ & $\begin{array}{l}\text { Solid wood wall with intermediate } \\
\text { insulation and rafter roof }\end{array}$ \\
\hline & & $\begin{array}{l}\text { Ventilated wall with wooden } \\
\text { paneling and ventilated rafter roof }\end{array}$ & $\begin{array}{l}\text { Concrete wall and roof with } \\
\text { external insulation }\end{array}$ \\
\hline & \multirow{2}{*}{$\begin{array}{l}\text { Twice that of existing building } \\
\text { in last floor }\end{array}$} & $\begin{array}{l}\text { Wall with cellulose insulation and } \\
\text { ventilated rafter roof }\end{array}$ & $\begin{array}{l}\text { Solid wood wall with intermediate } \\
\text { insulation and rafter roof }\end{array}$ \\
\hline & & $\begin{array}{l}\text { Ventilated wall with wooden } \\
\text { paneling and ventilated rafter roof }\end{array}$ & $\begin{array}{l}\text { Concrete wall and roof with } \\
\text { external insulation }\end{array}$ \\
\hline
\end{tabular}

Roofs (column A) were modeled as flat roof and sloping roof. The glazing areas (column B) of the new highest floors are simulated in 2 versions: in version 1 the glazing 
area of the highest floor is identical to the glazing area of the floors below and in version 2 the glazing area of the last floor is twice as large as the glazing area of the lower floors. The overall structure of the buildings was compared light-weight- (column C) and heavyweight-construction types (column D).

The build-up of the building shell followed the minimum requirements as defined in the Viennese Building Code, which in turn refers to the standards of the OIB Guideline $6(\mathrm{OIB}, 2019)$ in terms of energy efficiency in buildings. The U-values for the different construction types varied based on the actual wall or roof layers and overall build-up (Table 2). The different construction types were defined to meet but not exceed the requirements of the guideline. This was to ensure that only economically feasible construction types were applied for the different scenarios.

Table 2. Overview: Buildings extensions with different construction types [53].

\begin{tabular}{cccc}
\hline Construction Type Wall & U-Value $\left[\mathbf{W} / \mathbf{m}^{2} \mathbf{K}\right]$ & Construction Type Roof & $\begin{array}{c}\text { U-Value } \\
{\left[\mathbf{W} / \mathbf{m}^{2} \mathbf{K}\right]}\end{array}$ \\
\hline Wall with cellulose insulation & 0.190 & Inverted roof & 0.196 \\
\hline Ventilated wall with wooden paneling & 0.162 & Ventilated rafter roof & 0.104 \\
\hline Solid wood wall with intermediate insulation & 0.194 & Rafter roof & 0.115 \\
\hline Concrete wall with external insulation & 0.152 & Roof with external insulation & 0.129 \\
\hline
\end{tabular}

In addition to the different construction types, different greening scenarios for the roofs and facades were analyzed (Table 3). Differentiations were made in terms of the extent of the greening of the roof and the roof types were modeled with both a flat roof construction and sloping roof construction (column A). The construction of the roof was altered (column B), the flat roof with five different variants ranging from a traditional roof with no green layer to an extensive green roof and three options for the intensive green roofs with varying vegetation options between 10 and $90 \mathrm{~cm}$. The U-values (column C) decreased with the thickness of the substrate as the additional green layer acted like additional insulation. For the sloping roof, a distinction was only made between no greening and a minor extensive greening with $15 \mathrm{~cm}$. The limitation of the sloping roof lay in the actual angle, as only low height was feasible since substrate and vegetation layers could slide off with thicker construction heights. Since two different roof types were compared, the U-values differed, as the traditional roof was ventilated and thus featured a slightly better U-value.

Table 3. Overview: Buildings extensions with different green roof types [54].

\begin{tabular}{ccc}
\hline A. Roof Type & B. Greening of the Roof & U-Value $\left[\mathbf{W} / \mathbf{m}^{\mathbf{2}} \mathbf{K}\right]$ \\
\hline \multirow{3}{*}{ Flat Roof } & No greening $($ no substrate layer $)$ & 0.186 \\
\cline { 2 - 3 } & Extensive greening $(10 \mathrm{~cm})$ & 0.181 \\
\cline { 2 - 3 } & Intensive greening $(20 \mathrm{~cm})$ & 0.179 \\
\cline { 2 - 3 } & Intensive greening $(45 \mathrm{~cm})$ & 0.174 \\
\hline \multirow{2}{*}{ Sloping roof } & Intensive greening $(90 \mathrm{~cm})$ & 0.159 \\
\cline { 2 - 3 } & No greening (no substrate layer $)$ & 0.111 \\
\hline
\end{tabular}

\section{Results}

In this section the key findings were compiled based on the three methodologies described above: The (1) microclimate analysis, the (2) wind analysis, and the (3) energy and indoor climate comfort analysis. Each analysis addressed the same area as previously outlined, covering larger or smaller sample areas depending on the actual specific research 
question. The different scales of the simulations allowed for a detailed assessment of the overall effects of the densification within the specified areas.

\subsection{Microclimate Analysis: Key Results}

The microclimate analysis was carried by modeling the mean radiant temperature (MRT) since the ambient air temperature alone did not show significant differences between shaded and sunny places. The MRT is regarded as the weighted sum of all long- and shortwave radiant fluxes (direct, reflected, and diffuse), to which a human body is exposed. For an outdoor space, the MRT thus depends on the temperature of the sky, ground, vegetation, and surrounding buildings [57]. The MRT was assessed as the daily average for $24 \mathrm{~h}$, for the 12 daytime as well as the 12 nighttime hours using a reference period between 10 and 12 August 2014 to display representative boundary conditions for a heat wave in the Vienna. Within this analysis, the effect of the densification (increase in building height) was analyzed compared to the base case as well as the impacts of several greening scenarios on building and street level as outlined in the following Figures.

In a first assessment, the entire study area as displayed in Figure $3 a, b$ was applied. A 24-h analysis was carried out for both the base case as well as the densification scenario (Figure 7).
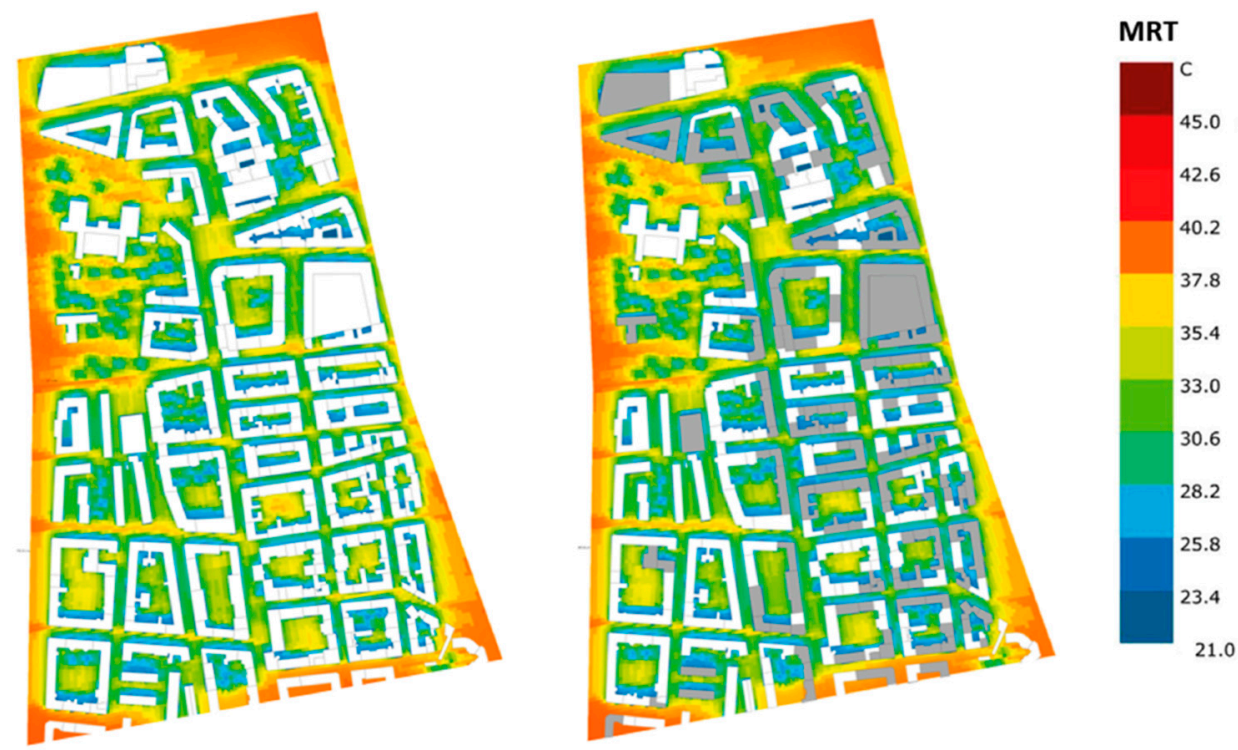

Figure 7. Twenty-four-hour mean radiant temperature (MRT) at street level for large-scale general densification impacts for base case (left) and densification scenario (right).

In order to assess the impact in more detail, a smaller sample area was extracted as previously depicted in Figure 3c,d. For this area a 12-h timeframe was chosen in addition to the 24-h to differentiate more clearly between daytime and nighttime temperatures (Figures 8 and 9).

The results show that general densification led to an obvious increase of shaded areas, which lead to in increased cooling over a period of time as the average exchange of radiative energy is reduced due to the incoming radiative flux being impeded by the deepened urban street canyons. This can be seen at street level between the buildings but also in the inner courtyards of the various building blocks. When buildings are extended on both sides of the street, the shading effect could be smaller as the upper floors are still exposed to incoming short-wave radiation. This effect could be more clearly seen in the smaller sample area, where the 24-h MRT showed a reduction of up to $4 \mathrm{~K}$ (Figure 8). 

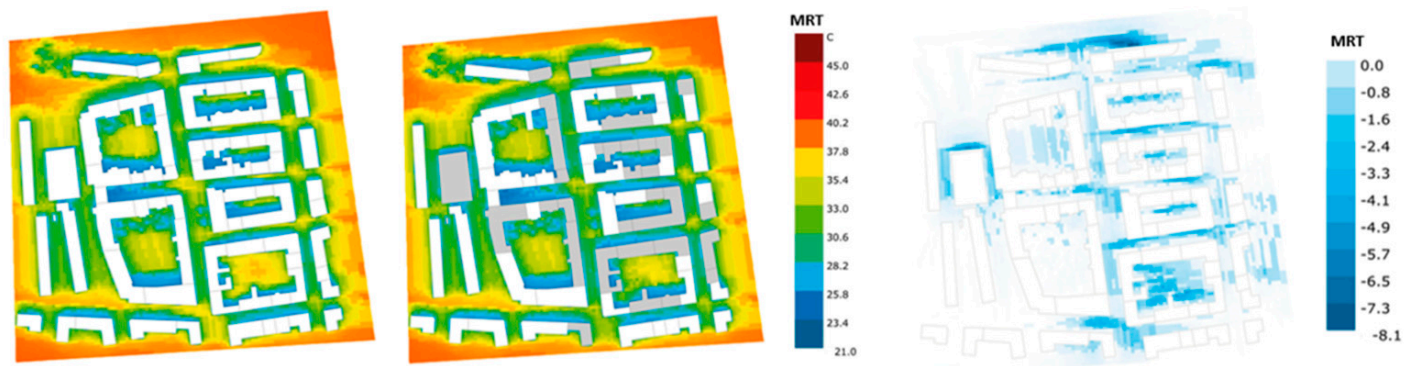

Figure 8. Twenty-four-hour MRT at street level for smaller sample area for base case (left) and densification scenario (middle) and 24-h MRT differences at street level between base case and densification scenario.

Whilst the 24-h analysis provided a meaningful indication of the overall shading effect due to the densification, the differentiation between daytime and nighttime temperatures delivered a clearer picture on the effects over time (Figure 9 (left) versus Figure 9 (right)) During the day, the cooling effect predominated due to the increased shading and subsequent reduced solar radiation. The long-wave radiation of the stored heat within the buildings did not change much at street levels due to the shadows of the higher buildings, thus protecting street level and lower floors from incoming short-wave radiation. The nighttime temperatures of the densification scenario were, however, higher compared to the based case due to the reduced sky view factor and subsequent lower nighttime cooling. The extended upper floors increased the total thermal mass of the building; however, at street level the downward air flow was limited inside the street canyons and courtyards.
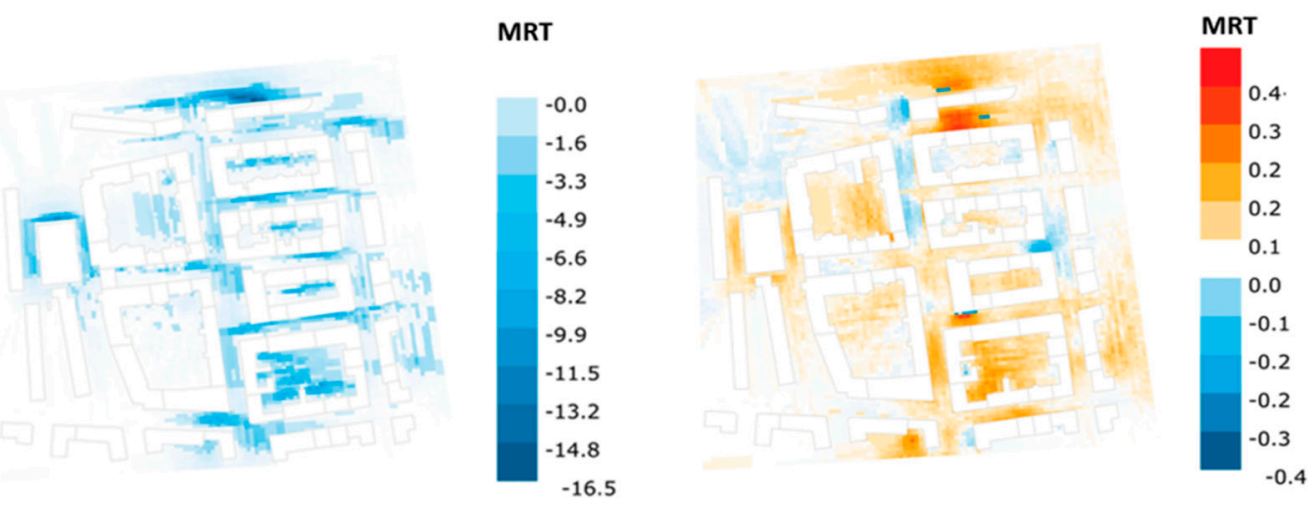

Figure 9. Twelve-hour MRT differences at street level between base case and densification scenario for smaller sample area for daytime (left) and nighttime (right).

In the third sample area, the impact of a high-rise building cluster as displayed in Figure 3e,f) was assessed. High-rise buildings lead to larger shaded areas over a longer daytime period in the vicinity of the buildings and subsequently to lower heat loads due to reduced solar radiation during the day. The results show that close to the high-rise building, there is a significant drop of MRT at street level from 38 to $23^{\circ} \mathrm{C}$ over a period of $24 \mathrm{~h}$ (Figure 10, top left and right). The 12-h MRT analysis highlighted that the daytime temperatures could reach comfortable levels due to the heavily shaded areas, whilst the nighttime MRT did not change significantly and ranged only up to an increase of $0.5 \mathrm{~K}$ (Figure 10 bottom left and right). 


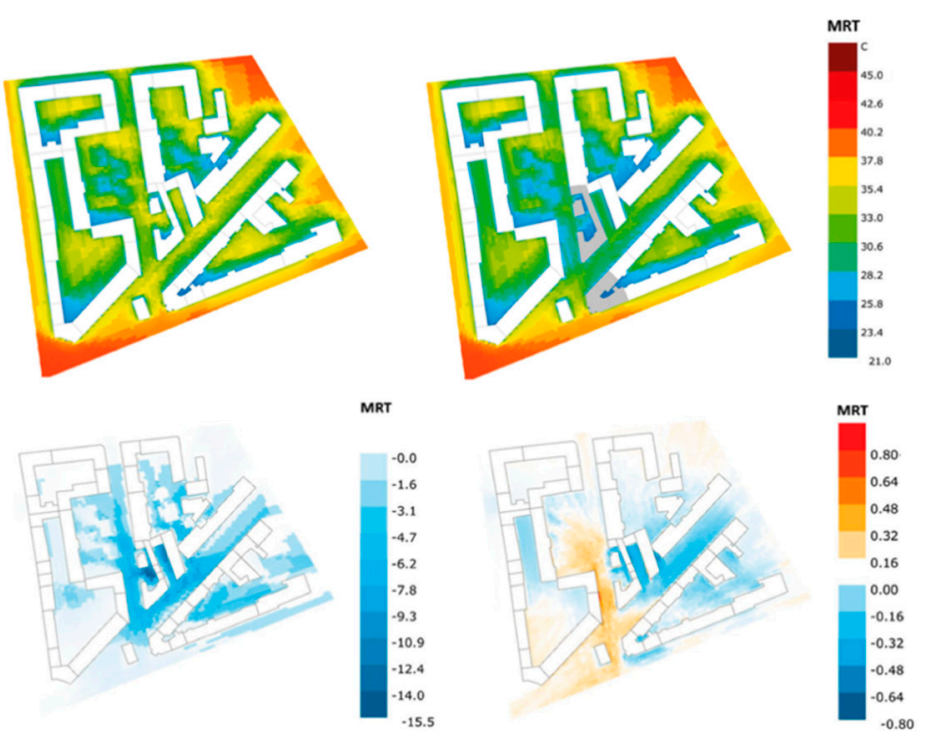

Figure 10. Twenty-four-hour MRT at street level for high-rise cluster for base case (top left) and densification scenario (top right) and 12-h MRT differences at street level between base case and densification scenario for smaller sample area for daytime (left) and nighttime (right).

In addition to the densification scenarios, the effect of several greening options on street and building level was explored within the small-scale sample area as depicted in Figure $3 \mathrm{c}$,d. For this comparative analysis, only the scenario with the already increased building height was selected. In Figure 11, the scenarios for additional green roofs, green facades, and trees at street level are displayed in 3D models.

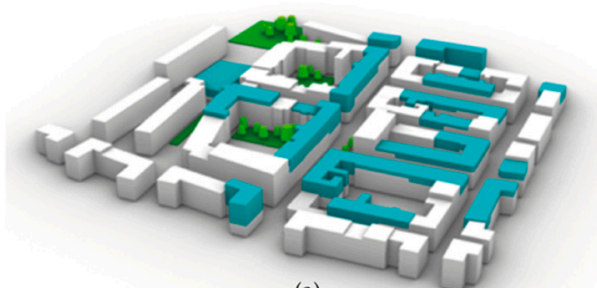

(a)

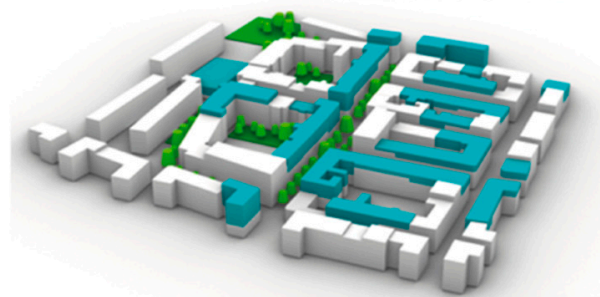

(c)

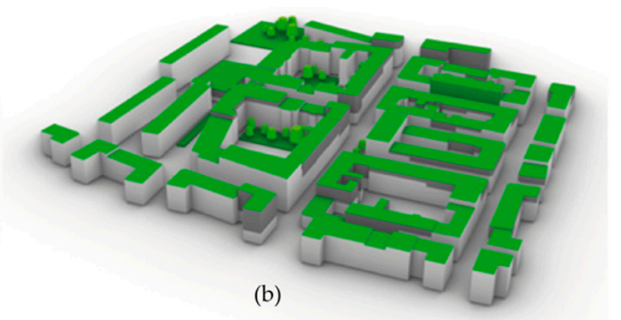

(b)

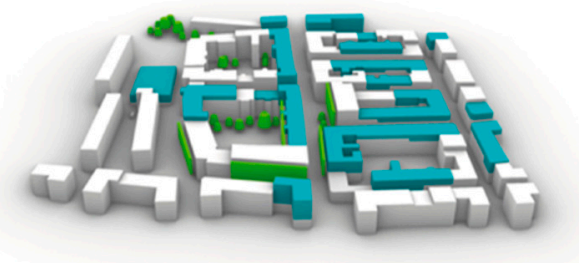

(d)

Figure 11. The 3D model of the smaller sample area for the microclimate simulations: for the initial densification scenario (a), for the densification scenario with green roofs (b), with additional trees at street level (c), and with green facades in a south-western street block (d).

The results of the 24-h street-level MRT distribution for the greening of the streets with additional trees are shown in Figure 12b: A positive cooling effect was observed due to the increased shading of the trees with an overall 24-h MRT reduction of up to $7 \mathrm{~K}$. Trees can shield building facades from the incoming solar radiation, leading to lower energy demand for cooling in buildings and shielding road surfaces, mitigating incoming solar radiation to the surface and allowing additional evapotranspiration. 

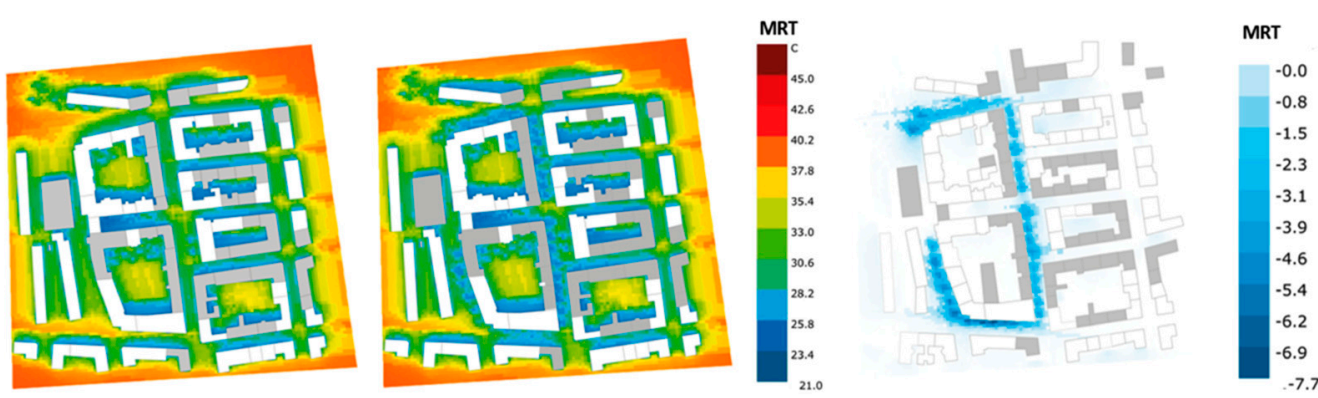

Figure 12. Twenty-four-hour MRT at street level for the smaller sample area with densification (left), densification and added trees at street level (middle), and the differences at street level between densification scenario without and with trees (right).

Whilst planting of additional green on street level showed clear benefits, the green roofs (see Figure 11c) did not show much positive effect on street level temperatures with an overall reduction of the 24-h MRT of around $0.5 \mathrm{~K}$ (Figure 13-left). The green roofs mostly contribute to lowering the air temperature on roof-top level rather than on streetlevel. Green facades (see Figure 11d) lead to lower temperatures in urban street canyons by shielding buildings from incoming solar radiation. Subsequently, heat exposure s reduced and cooling by evapotranspiration is increased, leading to a 24-h MRT reduction of up to $5 \mathrm{~K}$ (Figure 13-right).
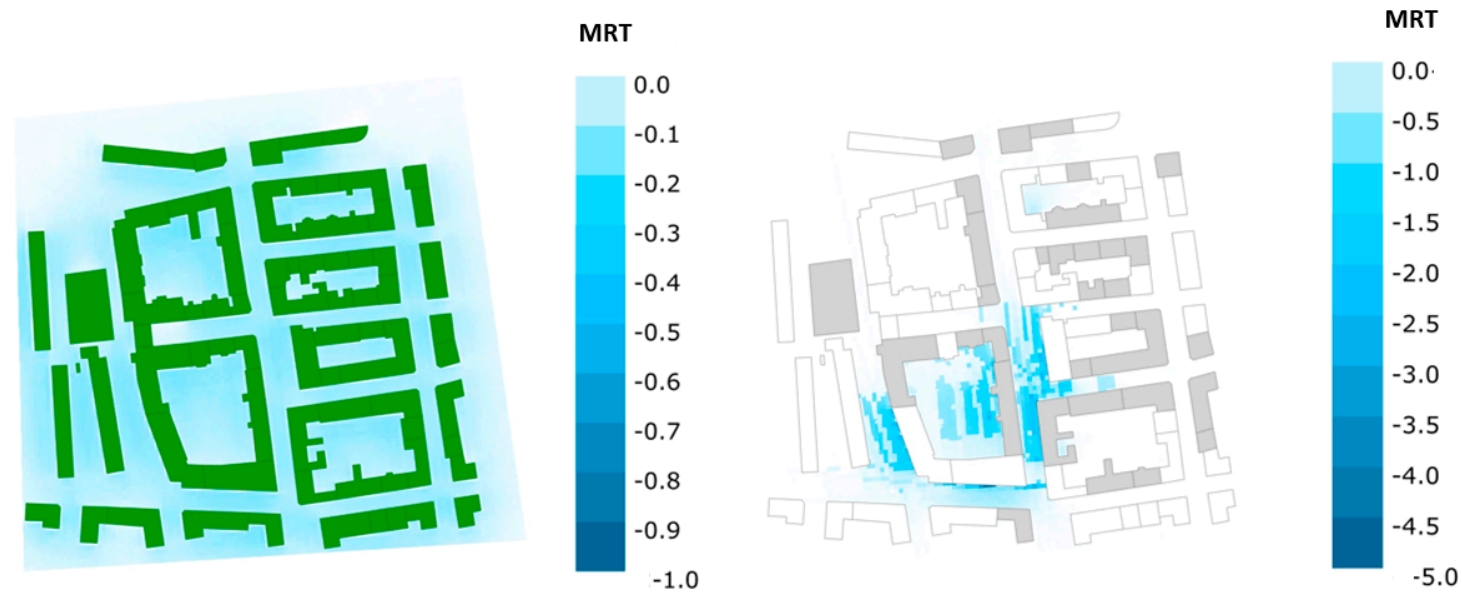

Figure 13. Twenty-four-hour MRT at street level for the smaller sample area with densification with additional green roofs (left) and green facades (right).

\subsection{Wind Analysis: Key Results}

The wind analysis highlighted the most significant effects the densification scenarios had on the wind speed and directions and subsequently the wind-comfort within the area. Wind simulations were carried out for the entire central Meidling area as shown in the previous section in Figure 5. The following Figures show examples of the key results. In Figure 14, which depicts one of the larger crossings at Meidlinger Hauptstraße, it can be seen that whilst the densification increased the wind speed at the crossing itself, the wind speed at the neighboring streets was decreased.

The length and direction of the green arrows in the Figure depict the changes in wind speed and direction; the yellow marker highlights the streets with the most significant changes.

Another street crossing was examined with wind direction from south-east (heat-wave scenario), as shown in Figure 15. The effect of increased building height could be observed in the right image compared with the left image. The wind was stronger in the base case, as it was not blocked by higher buildings. During heat waves, wind speeds can substantially 
decline by up to $50 \%$ in the densification scenario, which results in lower wind comfort as the ventilation in the street canyons decreases. Only on specific crossings, wind speeds could increase by up to $25 \%$. During a typical west wind scenario, however, the conditions did not significantly change.
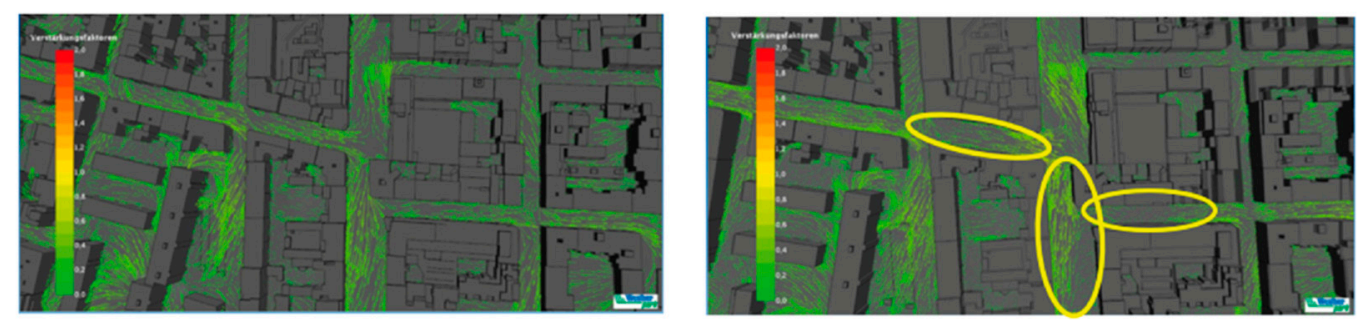

Figure 14. Changes in wind speed and direction for wind direction west for base case (left) and densification scenario (right) with streets with significant changes marked in yellow.
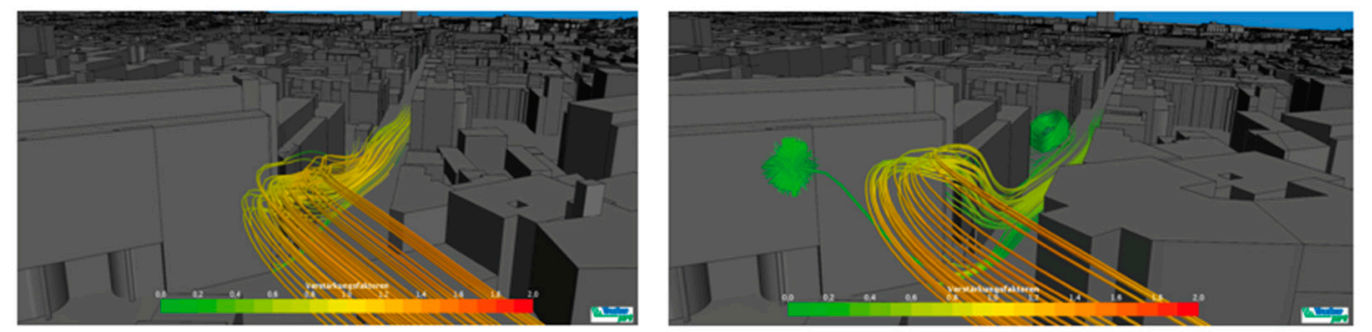

Figure 15. Changes in redirecting wind flow reducing wind speed for wind direction south-east for base case (left) and densification scenario (right).

A specific test case was carried out for the high-rise building densification scenario at the southern end of the development as depicted in Figure $3 \mathrm{e}, \mathrm{f}$ with a heat-wave simulation (south-east wind). Figure 16 shows that at the very street level on the corners and along the facades of the high-rise buildings, turbulences occur, leading to uncomfortable situations for pedestrians.
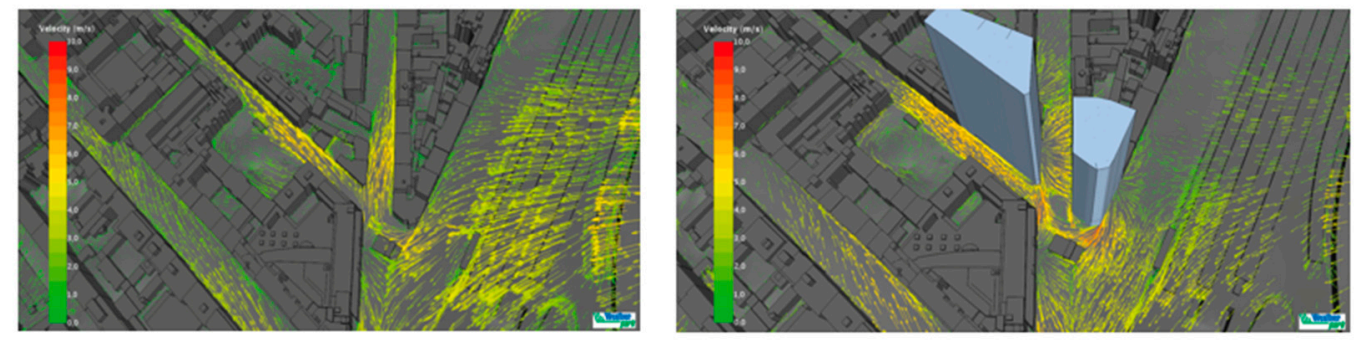

Figure 16. Changes in wind speed and direction for south-east wind direction for base case (left) and the high-rise buildings densification scenario (right).

Whilst south-easterly winds showed decreasing windspeed when high-rise buildings were established, westerly winds showed the opposite effect on wind comfort, as depicted in Figure 17. Hours of low wind comfort increased significantly with westerly winds, leading to uncomfortable wind situations in the streets near the potential high-rise buildings.

Overall, the high-rise building scenario showed that the impact on wind speed, direction, and pedestrian comfort could be significant in the vicinity of high-rise buildings; however, it depends very much on shape and location of the buildings to be erected. 

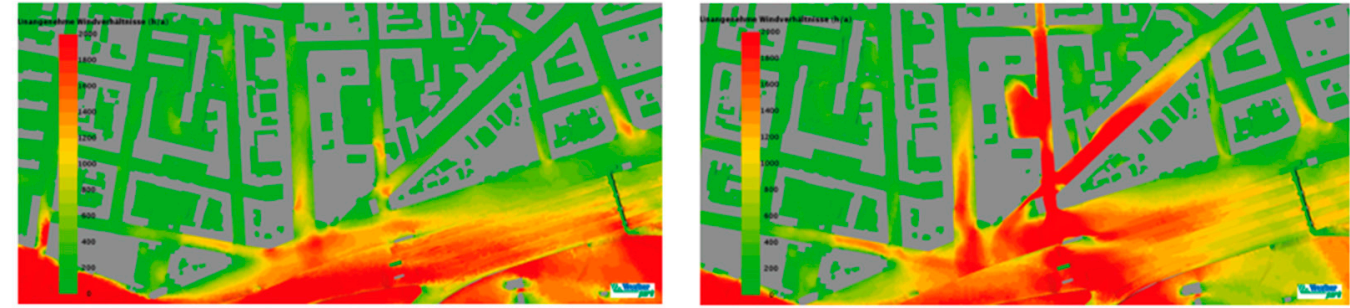

Figure 17. Changes in wind comfort for westerly wind direction for base case (left) and a high-rise buildings densification scenario (right).

\subsection{Energy and Indoor Climate Comfort Analysis: Key Results}

The energy and indoor climate comfort analysis was carried out to highlight the effect of the different construction types as outlined in Tables 1 and 2. For the indoor temperature simulations, the framework conditions were defined for a potential worst-case scenario: A top floor room with the potential highest solar gains was selected as the reference case, simulating the effects during one of the hottest days of the year with external daytime temperatures exceeding $30^{\circ} \mathrm{C}$. In order to create realistic circumstances, the room was modeled with natural nighttime ventilation with open windows between 11 p.m. and 8 a.m. If modeled without night-ventilation, the temperatures largely exceeded comfort limits well above $30^{\circ} \mathrm{C}$. Therefore, a scenario with ventilation needed to be considered in order to adequately compare effects of the different construction types. The framework conditions for the heating energy demand followed the current building regulations as noted in the previous section with weather data for the city of Vienna and an assessment over an entire year.

Figure 18 shows that the heating energy demand varied negligibly between the different variants (see the wall types in Table 4 below). The heavy-weight construction had only a slightly positive effect both in terms of heating energy demand as well as indoor room temperature. In the variants with the sloping roof, the indoor temperatures were generally $2-3^{\circ} \mathrm{K}$ higher compared to the flat roof construction due to the inclination of the roof and windows and the subsequently increased solar radiation. However, even with the sloping roof, the heavy-weight construction reached only around $1 \mathrm{~K}$ difference to the light-weight construction in terms of indoor room temperature.

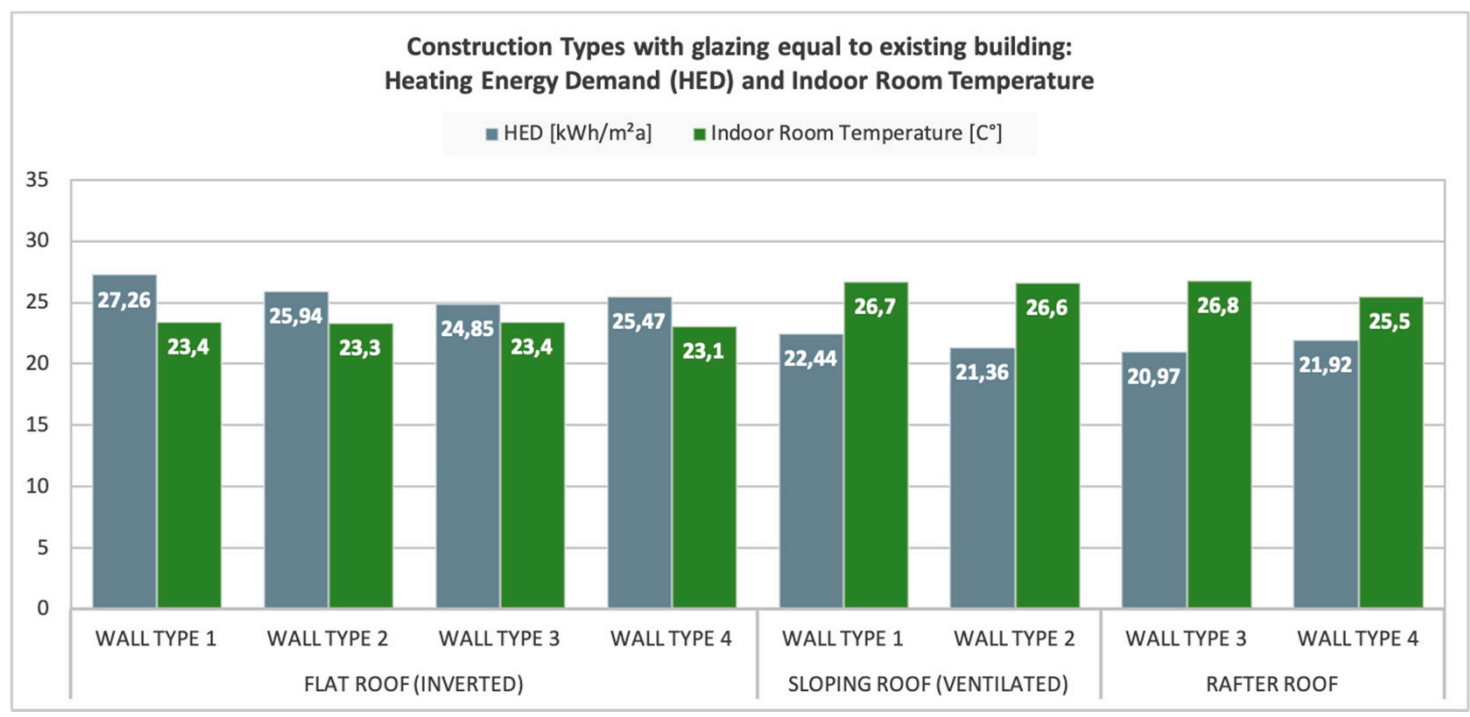

Figure 18. Heating energy demand and indoor room temperature for construction types with glazing equal to existing building (for wall type description see Table 4) [53]. 
Table 4. Wall type numbering and description for Figures 18 and 19 [53].

\begin{tabular}{cc}
\hline Wall Type Number & Wall Type Description \\
\hline Wall type 1 & Wall with cellulose insulation \\
\hline Wall type 2 & Ventilated wall with wooden paneling \\
\hline Wall type 3 & Solid wood wall with intermediate insulation \\
\hline Wall type 4 & Concrete wall with external insulation \\
\hline
\end{tabular}

The same variants were further analyzed with an increased glazing area. Figure 19 shows the results with twice the glazing area in the top floors compared to the existing building (see wall type descriptions in Table 4). Whilst the heating energy demand barely changed compared to the previous simulation with less glazing, the indoor temperature was, especially in the variant with the sloping roof and the subsequently angled glazing, considerably higher, although the effect of heavy-weight versus light-weight construction was only minimal. This showed that the transparent elements could have a far greater effect on indoor temperatures than different construction types, if the building quality of the building envelope (U-values) was already generally higher than noted in the building regulations. It is also evident that without further measures (e.g., adequate shading of the glazed areas; increased ventilation), the indoor temperatures by far exceeded comfortable indoor thermal conditions. Thus, the increased solar gains had to be specifically considered when planning with high glazing areas, which is especially relevant for the planning of attic extensions.

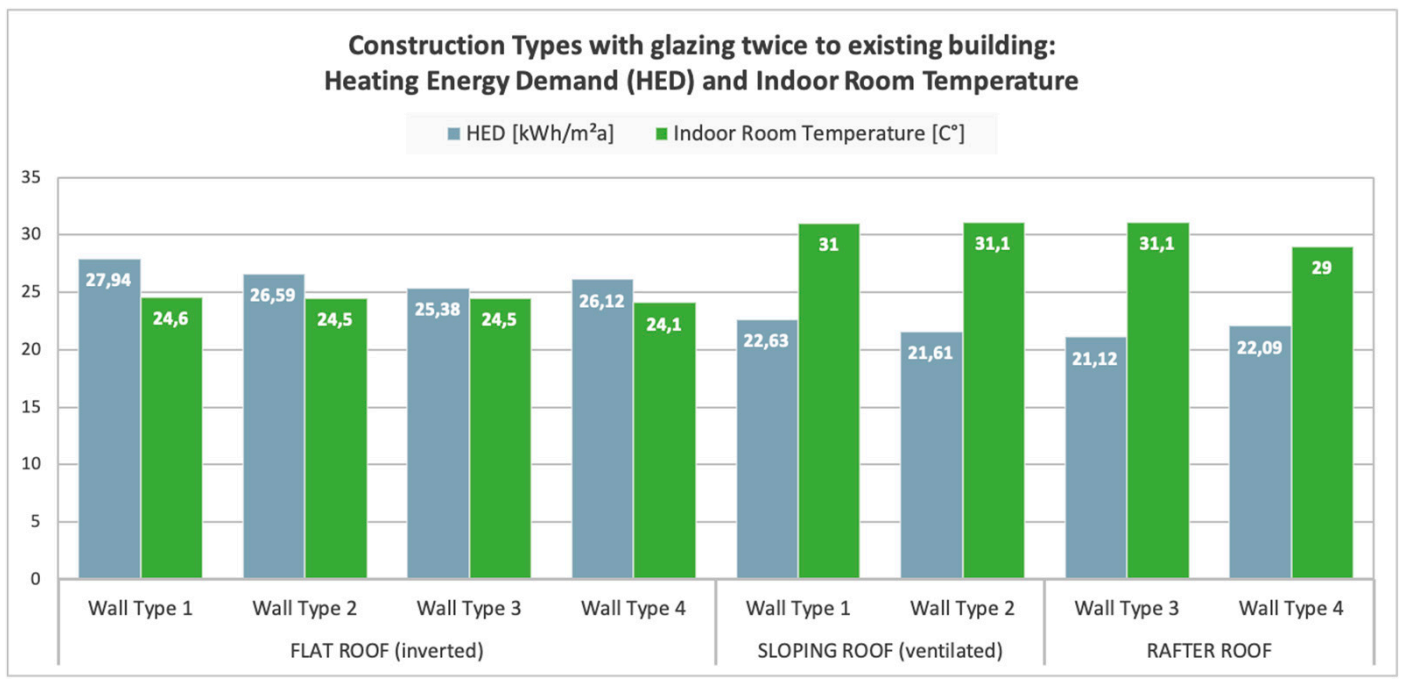

Figure 19. Heating energy demand and indoor room temperature for construction types with glazing twice to existing building (for wall type description see Table 4) [53].

In another assessment, the effects of green roofs and green facades were analyzed. The same construction types and framework conditions as outlined above were applied. In a first step, differentiations were made in terms of the extent of the greening of the roof (Table 3). In a first instance, roof types were modeled with both a flat roof construction and sloping roof construction. Secondly, the construction of the roof was altered. For the greening variants, the heating energy demand as well as the indoor room temperature were analyzed. Equal to the assessment for the construction types, for the calculation of the indoor room temperature, the same framework conditions were applied.

Figure 20 shows that there was only a negligible difference between the various greening options related to the heating energy demand. Similarly, the indoor room temperature in Figure 21 varied only marginally and was only slightly higher in the sloped roof option. This was, however, mainly due to the inclination of the roof and the increased solar ra- 
diation compared to the flat roof options. It showed that if the overall construction was already of high quality and subsequently well insulated, the added layer of the green roof generally had little effect on the heating energy demand and indoor temperatures.

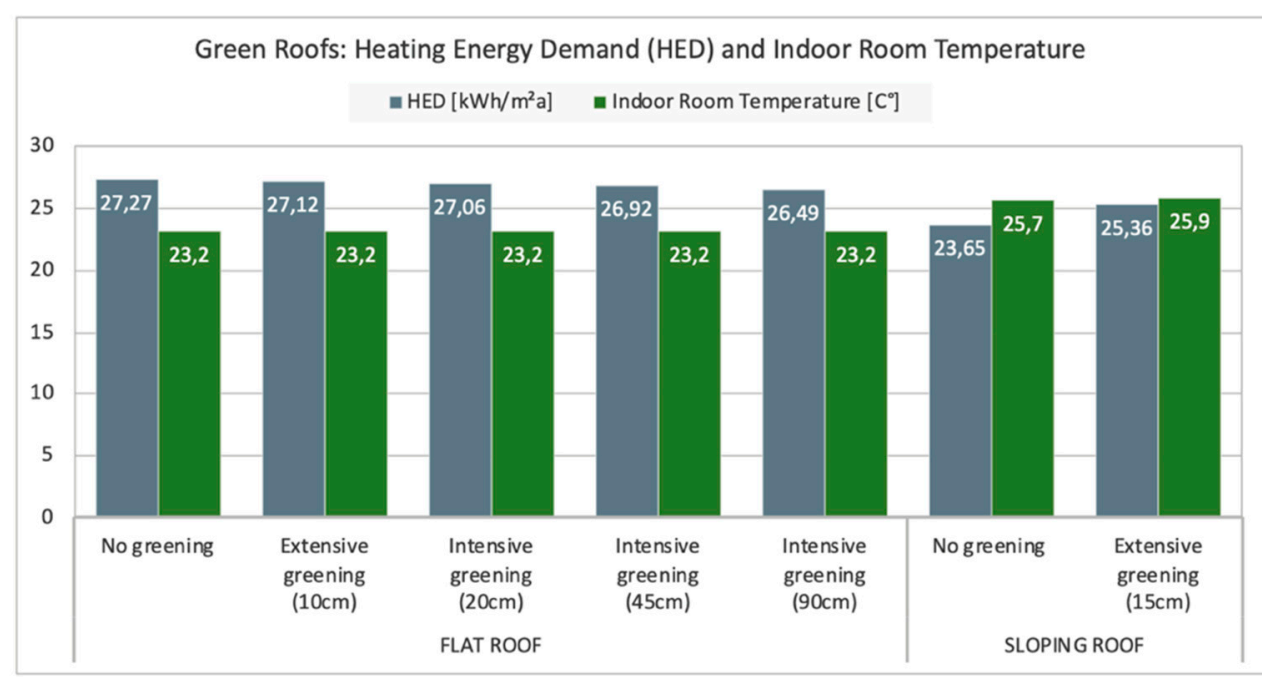

Figure 20. Heating energy demand and indoor room temperature for green roof construction types [54].

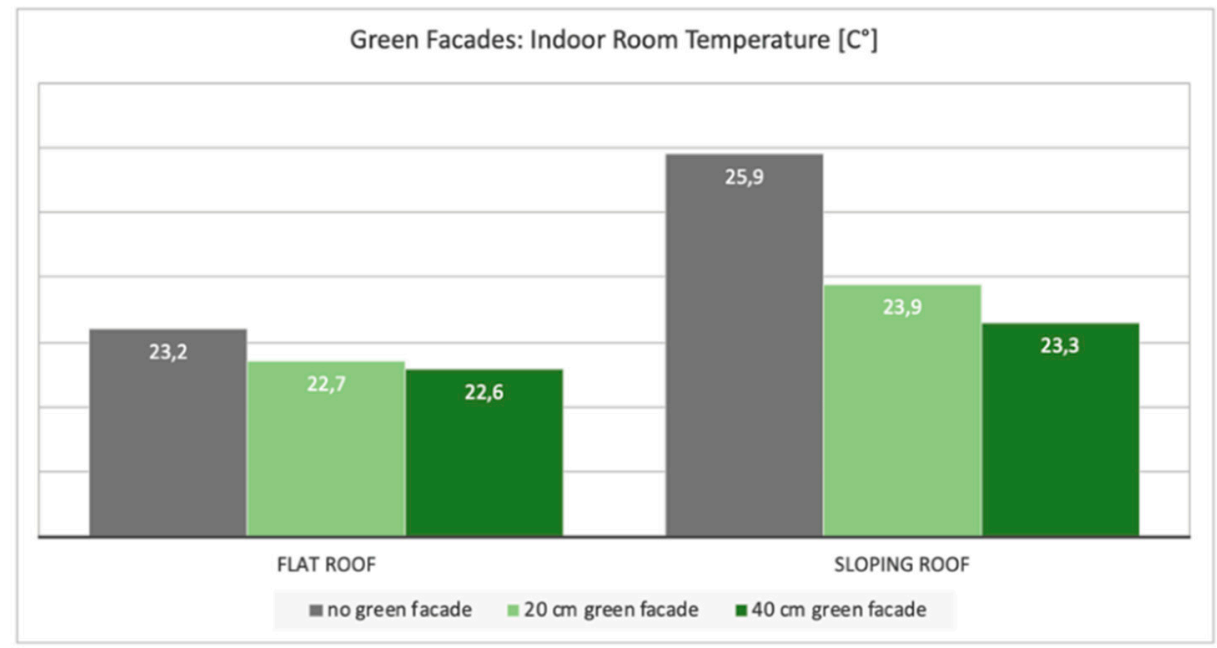

Figure 21. Indoor temperature for green roof facade construction types [54].

A further attempt was made to simulate green facades. However, due to the limited availability of adequate monitored data in relation to the physical properties and effects of the greenery, the analysis was limited to the shading effect of the plants. Thus, the actual effect of the evapotranspiration of the plants and the change in the microclimate was not considered. The green facades were modeled with an external layer that protruded either 20 or $40 \mathrm{~cm}$ from the actual facade. The greening was thus modeled with a shading effect that influenced the solar radiation reaching the windows. In the flat roof variant, the reduction in the maximum indoor temperature between the un-greened facade and a green area with a $20-\mathrm{cm}$ overhang was only $0.5 \mathrm{~K}$ and thus almost negligible. With a $40-\mathrm{cm}$ thick green area, the maximum temperature reduction is $0.6 \mathrm{~K}$. In the variant with the sloping roof the partial shading of the windows with the facade greening created a slightly stronger effect. With $20 \mathrm{~cm}$ facade greening, the temperature was reduced by $2 \mathrm{~K}$, and with $40 \mathrm{~cm}$ cantilevered greening, the difference increased to $2.6 \mathrm{~K}$. However, it should be noted that the same shading effect could be achieved with any other material. 


\section{Discussion}

Based on the hypothesis that specific urban and building densification measures could have a positive or negative impact on the urban microclimate, the building energy demand as well as the external (street level) and internal (building) comfort level, this paper focused on the quantification of these impacts. As the main aim was to assess which measures related to urban and building planning could be most effective, the key findings can be summarized as follows.

The results of the microclimate simulations show that large-scale densification led to an increase in shaded areas and enhanced local cooling at street level and inner courtyards during the day as the mean radiation temperature dropped between 3 and $10 \mathrm{~K}$ MRT (mean radiant temperature), especially in west-east-oriented streets. At night, the mean radiation temperature only increased slightly up to $0.5 \mathrm{~K}$ MRT. A reduction in wind speed by $50 \%$ (from approximately $6 \mathrm{~m}$ to $3 \mathrm{~m} / \mathrm{s}$ ) led to an increase in the mean radiation temperature of 1 to $3 \mathrm{~K}$ MRT during the day and an increase of 0.1 to $0.3 \mathrm{~K}$ MRT at night. High-rise buildings led to larger shaded areas over a longer period and due to limited solar radiation, which resulted in mean radiation temperature drops by up to $15 \mathrm{~K}$ MRT. The effect during the night was almost negligible with a simulated increase of up to $0.5 \mathrm{~K}$ MRT.

Greening the urban landscape on street or building level is widely seen as an appropriate adaptation measure to mitigate the urban heat island effect. Street greening as an adaptation measure contributes to a significant reduction in the radiation temperature. Shaded zones on street level can be reduced by up to $15 \mathrm{~K}$ MRT during daytime. At night there is only a slight reduction in the radiation temperature by a few tenths of $1 \mathrm{~K}$ MRT. Green facades contributed to a significant reduction in the external radiation temperature. During the day, the radiation temperature in the shaded zones was reduced by up to $15 \mathrm{~K}$ MRT, whilst during nighttime there was only a slight reduction in the radiation temperature by a few tenths of $1 \mathrm{~K}$ MRT.

Green roofs caused a slight reduction in the external radiation temperature by a few $1 / 10 \mathrm{~K}$ MRT at street level, both during day and night. On roof level, green roofs could reduce the radiation temperature by $0.5 \mathrm{~K}$ MRT (without the application of intensive greening such as large trees). The effect of green roofs was negligible if the building was already well insulated. Any effect was thus mainly related to the height of the substrate layer, which acted like an added insulating layer on top of the building. Green facades can influence the indoor temperatures due to their shading properties. Partially shading the windows (e.g., through floor-based facade greening) had the greatest effect in reducing the indoor temperature as it acted like an external shading system. However, it must be noted that due to missing data related to the physical properties of plants (e.g., evapotranspiration), the potential change in microclimate was not considered in the assessment of the building energy demand or internal conditions.

The effects of heavy-weight or light-weight rooftop extensions on the energy demand and thermal comfort within the building were overall minimal compared to the impact of the glazing area. High thermal storage capacities could not adequately compensate for a lack of shading measures for large glazing areas or a lack of appropriate ventilation measures. For window areas that are not shaded by external shading systems, the size of the window had a greater effect than the thermal mass. Night ventilation as a passive measure was highly relevant in light-weight and heavy-weight constructions to keep the indoor temperatures within the comfort limits. This also confirmed other studies related to passive measures to avoid summertime overheating [33,34].

Based on these results and stakeholder consultations with relevant experts from the city administration and planning departments in Vienna, several key recommendations were derived:

(1) Large scale densification with a moderate increase in building height should consider the shading of south and west oriented facades through facade greening and trees, the shading of rooftop extensions, and proper orientation of buildings and streets to reduce solar irradiance and improve natural ventilation. Vertical densification 
should be linked to specific requirements related to external shading and ventilation measures (e.g., cross and night ventilation);

(2) For high-rise densification, the building design and orientation should be planned in consideration of main wind-directions and reflections of glass facades. These aspects must be evaluated by means of mandatory individual microclimate and wind-comfort assessments;

(3) Urban greening should focus on the street levels in order to increase evaporation and humidity, as well as decrease heat exposure through shading. Trees should be planted along the northern and eastern street sides, exposed to the sun during the hours with highest sun radiation. Soil sealing should be reduced including in private yards and large public places to increase evaporation. Greening on street level should be mandatory on both the plot area (courtyard areas) and on public areas (private and public sector);

(4) Building greening on facades should be considered in conjunction with the use of renewable energy systems, since an increase in indoor comfort in summer is achieved primarily through shading during hot periods. Facade greening should also be primarily be implemented at street level, since the evaporation and shading effect can reduce the radiation temperature and the perceived temperature at street level. Rooftop greening has hardly an influence on microclimate at street level. (Extensive) green roofs act primarily as thermal insulation for the buildings; however, the better the insulation of the roof underneath, the smaller the effect of the green roof on the energy demand and indoor temperatures of the building.

\section{Conclusions}

Densification in cities is undoubtedly a valid strategy to avoid extensive urban sprawl into surrounding suburbia. Cities growing in population are, however, increasingly confronted with the conflicting targets of catering enough living and associated infrastructure space for their inhabitants and at the same time providing a high quality of life with comfortable external and indoor environments. The increased sealing of surfaces, the inherent density of tight urban spaces, and the high thermal mass influence the urban microclimate in relation to the ventilation of the streetscape, the heat island effect and the subsequent effect on the buildings. Densification, however, also provides a chance to implement sustainable climate adaptation and mitigation strategies if appropriate measures are selected. The results from this paper highlight that the effects of densification are diverse and manifold and can both have positive as well as negative implications on the urban microclimate, energy demand, as well as external and internal comfort.

Therefore, one of the key conclusions is that it is absolutely essential to simulate and assess the specific densification measures at an early planning stage in order to exploit the potential benefits such as increased comfort temperatures at street level, whilst at the same time limiting the negative effects, such as, e.g., uncomfortable wind conditions. Providing simulations at an early urban planning level for land-use and zoning plans could support an adequate urban development, which takes the impact on the urban microclimate into account. Improving the respective tools to combine the assessments within one environment, especially one that considers both the effects of microclimate on an external, urban scale as well as on the internal, building scale will be a prerequisite in order to foster a truly integrated approach.

Author Contributions: Conceptualization, W.L.; methodology, analysis, and visualizations, W.L., M.V., M.R., S.T., and D.Ö.; writing—original draft preparation, W.L. and D.Ö.; writing—review and editing, W.L. and D.Ö.; project administration and funding acquisition, G.E. All authors have read and agreed to the published version of the manuscript.

Funding: This research was funded within the project "CLUDEX-Climate Change and urban densification impact exploration-heat exposure reduction through roof scape adaptation-a large scale case study" under the 10th Call of the Austrian Climate Research Program (ACRP) by the Austrian Climate and Energy Fund, Grant number KR17AC0K13790, Project Number B769976. 
Institutional Review Board Statement: Not applicable.

Informed Consent Statement: Not applicable.

Data Availability Statement: The study contains model results and do not contain monitoring or personal data. Spatial results are array data depicted as maps included as Figures to the article. Results of simulations of thermal Indoor conditions are again arrays of gridded data. They are averaged and depicted in tables and bar charts-numbers are included in the charts. Array data can be provided through the authors on request.

Conflicts of Interest: The authors declare no conflict of interest.

\section{References}

1. IPCC. Climate Change Synthesis Report. Contribution of Working Groups I, II and III to the Fifth Assessment Report of the Intergovernmental Panel on Climate Change; Core Writing Team, Pachauri, R.K., Meyer, L.A., Eds.; IPCC: Geneva, Switzerland, 2014.

2. United Nations Climate Change. The Paris Agreements, 4th November 2016. Available online: https://unfccc.int/files/essential_ background/convention/application/pdf/english_paris_agreement.pdf (accessed on 16 June 2020).

3. Seto, K.C.; Fragkias, M.; Guneralp, B.; Reilly, M.K. A Meta-Analysis of Global Urban Land Expansion. PLoS ONE 2011, 6, 9. [CrossRef] [PubMed]

4. United Nations, Department of Economic and Social Affairs, News. 68\% of the World Population Projected to Live in Urban Areas by 2050, Says UN. Available online: https:/ / www.un.org/development/desa/en/news/population/2018-revision-ofworld-urbanization-prospects.html (accessed on 22 July 2020).

5. Bradbury, M.; Peterson, M.N.; Liu, J. Long-term dynamics of household size and their environmental implications. Popul. Environ. 2014, 36, 73-84. [CrossRef]

6. Carneiro Freire, S.; Corban, C.; Ehrlich, D.; Florczyk, A.; Kemper, T.; Maffenini, L.; Melchiorri, M.; Pesaresi, M.; Schiavina, M.; Tommasi, P. Atlas of the Human Planet; Publications Office of the European Union: Luxembourg, 2019; ISBN 978-92-76-14132-7. [CrossRef]

7. Stadt Wien, Magistratsabteilung 23-Wirtschaft, Arbeit und Statistik, Wien in Zahlen, Bevölkerungsprognose. 2018. Available online: https:/ / www.wien.gv.at/statistik/pdf/bev-prog-2018.pdf (accessed on 16 June 2020).

8. Stadt Wien, Wiener Umweltschutzabteilung (MA22). Öffentlich Zugängliche Grünflächen-Analyse. Stadt Wien. 2020. Available online: https:/ / www.wien.gv.at/umweltschutz/umweltgut/oeffentlich.html (accessed on 10 May 2020).

9. Zuvela-Aloise, M. Future of Climatic Urban Heat Stress Impacts-Adaption and Mitigation of the Climate Change Impact on Urban Heat Stress Based on Model Runs Derived with an Urban Climate Model; Endbericht zum Projekt FOCUS I, Klima- und Energiefonds: Wien, Austria, 2013. Available online: https:/ /www.klimafonds.gv.at/wp-content/uploads/sites/6/03032015FOCUSZuvelaAloiseEBACRP2B060373.pdf (accessed on 10 May 2020).

10. Fokaides, P.A.; Kylili, A.; Nicolaou, L.; Ioannou, B. The effect of soil sealing on the urban heat island phenomenon. Indoor Built Environ. 2016, 25, 1136-1147. [CrossRef]

11. Kottmeier, C.; Biegert, C.; Corsmeier, U. Effects of urban land use on surface temperature in Berlin: Case study. J. Urban Plan. Dev. 2007, 133, 128-137. [CrossRef]

12. Conticelli, E.; Proli, S.; Tondelli, S. Integrating energy efficiency and urban densification policies: Two Italian case studies. Energy Build. 2017, 155, 308-323. [CrossRef]

13. McEvoy, D.; Lindley, S.; Handley, J. Adaptation and mitigation in urban areas: Synergies and conflicts. Proc. Inst. Civil Eng. Munic. Eng. 2006, 159, 185-191. [CrossRef]

14. Loibl, W.; Vuckovics, M.; Etminan, G.; Österreicher, D.; Ratheiser, M.; Tschannett, S. Climate Change and Urban Densification Impact Exploration-Heat Exposure Reduction Through Roof Scape Adaptation-A Large Scale Case Study; Project Number: B769976, ACRP Final Report-Activity Report; AIT Austrian Institute of Technology: Vienna, Austria, 2020.

15. Mahtta, R.; Mahendra, A.; Seto, K.C. Building up or spreading out? Typologies of urban growth across 478 cities of 1 million+. Environ. Res. Lett. 2019, 14, 13. [CrossRef]

16. Jaksch, S.; Franke, A.; Österreicher, D.; Treberspurg, M. A systematic approach to sustainable urban densification using prefabricated timber-based attic extension modules. In Energy Procedia, Proceedings of the SBE16 Tallinn and Helsinki Conference; Build Green and Renovate Deep, Tallinn, Estonia, 5-7 October 2016; Elsevier Ltd.: Amsterdam, The Netherlands, 2016; ISBN 1876-6102. [CrossRef]

17. Ghofrani, Z.; Sposito, V.; Faggian, R. A Comprehensive Review of Blue-Green Infrastructure Concepts. Int. J. Environ. Sustain. 2017, 6, 15-36. [CrossRef]

18. Alves, A.; Vojinovic, Z.; Kapelan, Z.; Sanchez, A.; Gersonius, B. Exploring trade-offs among the multiple benefits of green-bluegrey infrastructure for urban flood mitigation. Sci. Total Environ. 2020, 703, 14. [CrossRef]

19. Belcakova, I.; Swiader, M.; Bartyna-Zielinska, M. The Green Infrastructure in Cities as a Tool for Climate Change Adaptation and Mitigation: Slovakian and Polish Experiences. Atmosphere 2019, 10, 552. [CrossRef]

20. Brandenburg, C.; Damyanovic, D.; Reinwald, F.; Allex, B.; Gantner, B.; Czachs, C. Urban. Heat Islands Strategieplan; Magistrat der Stadt Wien; Wiener Umweltschutzabteilung (MA 21): Vienna, Austria, 2015. 
21. Virk, G.; Jansz, A.; Mavrogianni, A.; Mylona, A.; Stocker, J.; Davies, M. The effectiveness of retrofitted green and cool roofs at reducing overheating in a naturally ventilated office in London: Direct and indirect effects in current and future climates. Indoor Built Environ. 2014, 23, 504-520. [CrossRef]

22. Sharma, A.; Woodruff, S.; Budhathoki, M.; Hamlet, A.F.; Chen, F.; Fernando, H.J.S. Role of green roofs in reducing heat stress in vulnerable urban communities-a multidisciplinary approach. Environ. Res. Lett. 2018, 13, 13. [CrossRef]

23. Treberspurg, M.; Streicher, W.; Reim, T.H. Sommertauglichkeit im Gebäudebestand. Wohnbauforschung des Bundes; F1494; Smart CityWien: Vienna, Austria, 2011.

24. Chun, B.; Guldmann, J.M. Impact of greening on the urban heat island: Seasonal variations and mitigation strategies. Comput. Environ. Urban. Syst. 2018, 71, 165-176. [CrossRef]

25. Ciriminna, R.; Meneguzzo, F.; Pecoraino, M.; Pagliaro, M. Solar Green Roofs: A Unified Outlook 20 Years On. Energy Technol. 2019, 7, 7. [CrossRef]

26. Sattler, S.; Zluwa, I.; Österreicher, D. The "PV Rooftop Garden": Providing Recreational Green Roofs and Renewable Energy as a Multifunctional System within One Surface Area. Appl. Sci. 2020, 10, 1791. [CrossRef]

27. Skelhorn, C.P.; Levermore, G.; Lindley, S.J. Impacts on cooling energy consumption due to the UHI and vegetation changes in Manchester, UK. Energy Build. 2016, 122, 150-159. [CrossRef]

28. Duan, S.P.; Luo, Z.W.; Yang, X.Y.; Li, Y.G. The impact of building operations on urban heat/cool islands under urban densification: A comparison between naturally-ventilated and air-conditioned buildings. Appl. Energy 2019, 235, 129-138. [CrossRef]

29. Bevilacqua, P.; Mazzeo, D.; Arcuri, N. Thermal inertia assessment of an experimental extensive green roof in summer conditions. Build. Environ. 2018, 131, 264-276. [CrossRef]

30. Gupta, R.; Gregg, M. Assessing energy use and overheating risk in net zero energy dwellings in UK. Energy Build. 2018, 158, 897-905. [CrossRef]

31. McLeod, R.S.; Hopfe, C.J.; Kwan, A. An investigation into future performance and overheating risks in Passivhaus dwellings. Build. Environ. 2013, 70, 189-209. [CrossRef]

32. Oikonomou, E.; Davies, M.; Mavrogianni, A.; Biddulph, P.; Wilkinson, P.; Kolokotroni, M. Modelling the relative importance of the urban heat island and the thermal quality of dwellings for overheating in London. Build. Environ. 2012, 57, 223-238. [CrossRef]

33. Handler, S.; Korjenic, A.; Bednar, T. The influence of external thermal insulation composite systems on the summer performance of buildings. Bauphysik 2011, 33, 225-233. [CrossRef]

34. Österreicher, D.; Sattler, S. Maintaining Comfortable Summertime Indoor Temperatures by Means of Passive Design Measures to Mitigate the Urban Heat Island Effect-A Sensitivity Analysis for Residential Buildings in the City of Vienna. Urban. Sci. 2018, 2, 66. [CrossRef]

35. Mlakar, J.; Strancar, J. Overheating in residential passive house: Solution strategies revealed and confirmed through data analysis and simulations. Energy Build. 2011, 43, 1443-1451. [CrossRef]

36. Stazi, F.; Tomassoni, E.; Di Perna, C. Super-insulated wooden envelopes in Mediterranean climate: Summer overheating, thermal comfort optimization, environmental impact on an Italian case study. Energy Build. 2017, 138, 716-732. [CrossRef]

37. Sameni, S.M.T.; Gaterell, M.; Montazami, A.; Ahmed, A. Overheating investigation in UK social housing flats built to the Passivhaus standard. Building Environ. 2015, 92, 222-235. [CrossRef]

38. Adekunle, T.O.; Nikolopoulou, M. Thermal comfort, summertime temperatures and overheating in prefabricated timber housing. Building Environ. 2016, 103, 21-35. [CrossRef]

39. Austrian Standards. ÖNORM B 8110-3. Wärmeschutz im Hochbau-Teil 3: Vermeidung Sommerlicher Überwärmung; Austrian Standards: Vienna, Austria, 2020.

40. Kim, H.; Anderson, K. Energy Modeling System Using Building Information Modeling Open Standards. J. Comput. Civ. Eng. 2013, 27, 203-211. [CrossRef]

41. Perez, D.; Robinson, D. Urban Energy Flow Modelling: A Data-Aware Approach. In Digital Urban Modeling and Simulation. Communications in Computer and Information Science; Arisona, S.M., Aschwanden, G., Halatsch, J., Wonka, P., Eds.; Springer: Berlin/Heidelberg, Germany, 2012; Volume 242.

42. Groger, G.; Plumer, L. CityGML-Interoperable semantic 3D city models. ISPRS J. Photogramm. Remote Sens. 2012, 71, 12-33. [CrossRef]

43. Agugiaro, G. First steps towards an integrated CityGML-based 3D model of Vienna. In Proceedings of the XXIII ISPRS Congress, Commission, Prague, Czech Republic, 12-19 July 2016. [CrossRef]

44. Biljecki, F.; Ledoux, H.; Stoter, J. Does a finer level of detail of a 3D city model bring an improvement for estimating shadows? In Advances in 3D Geoinformation; Springer International Publishing: Cham, Switzerland, 2016.

45. Rhinoceros, G. Available online: https:// www.rhino3d.com (accessed on 24 July 2020).

46. City of Vienna, MA21. Land Use and Zoning Plan. 2020. Available online: https://www.wien.gv.at/flaechenwidmung/public/ (accessed on 24 July 2020). 
47. Loibl, W.; Etminan, G.; Österreicher, D.; Ratheiser, M.; Stollnberger, R.; Tschannett, S.; Tötzer, T.; Vuckovic, M.; Walal, K. Urban densification and urban climate change-assessing interaction through densification scenarios and climate simulations. In Proceedings of the 24th International Conference on Urban Planning and Regional Development in the Information Society, GeoMultimedia, Karlsruhe, Germany, 2-4 April 2019. Available online: https:/ / conference.corp.at/index.php?id=38\&L=0 (accessed on 19 August 2020).

48. Food4Rhino. Available online: https://www.food4rhino.com/app/ladybug-tools (accessed on 24 July 2020).

49. Vuckovic, M.; Loibl, W.; Tötzer, T.; Stollnberger, R. Potential of Urban Densification to Mitigate the Effects of Heat Island in Vienna, Austria. Environments 2019, 6, 82. Available online: https://doi.org/10.3390/environments6070082/ (accessed on 19 August 2020). [CrossRef]

50. Loibl, W.; Züger, H.; Köstl, M. Reclip:century-Entwicklung eines Basisdatensatzes regionaler Klimaszenarien. Proceedings of 11. Österreichischen Klimatag "Klima im Wandel, Auswirkungen und Strategien” 2010. Available online: http:/ / www.austroclim. at/fileadmin/user_upload/ppt_11.Klimatag/Tagungsband_upload.pdf (accessed on 19 August 2020).

51. STAR-CCM+. 2020. Available online: https://www.plm.automation.siemens.com/global/en/products/simcenter/STAR-CCM html (accessed on 19 August 2020).

52. Yuan, C.; Rena, C.; Ng, E. GIS-based surface roughness evaluation in the urban planning system to improve the wind environmentA study in Wuhan, China. Urban. Clim. 2014, 10, 585-593. Available online: https:/ / doi.org/10.1016/j.uclim.2014.06.005 (accessed on 19 August 2020). [CrossRef]

53. Zwirschitz, S. Energetische Analyse von Nachverdichtungsvarianten im Urbanen Wohnbau am Beispiel eines dicht Bebauten Wiener Stadtviertels. Master's Thesis, University of Natural Resources and Life Sciences, Vienna, Austria, 2020.

54. Vansco, D. Auswirkung der Gebäudebegrünung auf den Innenraumkomfort im Urbanen Wohnbau am Beispiel eines dicht bebauten Wiener Stadtviertels. Master's Thesis, University of Natural Resources and Life Sciences, Vienna, Austria, 2020.

55. ArchiPhysik. 2020. Available online: https://archiphysik.at/ (accessed on 24 July 2020).

56. Thesim3d. 2020. Available online: http:/ / www.thesim.at (accessed on 24 July 2020).

57. Lindberg, F.; Holmer, B.; Thorsson, S.; Rayner, D. Characteristics of the mean radiant temperature in high latitude citiesimplications for sensitive climate planning applications. Int. J. Biometeorol. 2014, 58, 613-627. [CrossRef] [PubMed] 